\title{
LA DESAPARECIDA CAPILLA DE DON LOPE DE MENDOZA: NUEVOS DATOS SOBRE SUS RETABLOS, LOS SEPULCROS, SU CORO ALTO Y LA SACRISTIIA
}

\author{
ALBERTO FERNÁNDEZ GONZÁLEZ
}

\begin{abstract}
Resumen
De la desaparecida capilla bajomedieval que el arzobispo don Lope de Mendoza fundó en la catedral de Santiago apenas tenemos información precisa que permita conocer adecuadamente sus características. A partir del hallazgo de nuevas noticias documentales, que incluyen descripciones, contratos, testamentos y un significativo plano de 1739 , se pueden aportar interesantes datos sobre algunos aspectos de su arquitectura y sepulcros $y$, sobre todo, reconstruir el amueblamiento de este importante recinto catedralicio.
\end{abstract}

\section{Palabras Clave}

Arzobispo don Lope de Mendoza. Catedral de Santiago. Capilla bajomedieval. Sepulcros. Retablos de la Edad Moderna. Arquitectura gótica.

\begin{abstract}
Very little precise information remains on the exact characteristics of the no longer existing early medieval chapel founded by Archbishop Lope de Mendoza in the Cathedral of Santiago. Following the discovery of new documentary findings including descriptions, contracts, wills and a significant map of 1739 , interesting facts about certain aspects of its architecture and tombs have been brought to light and, above all, we are able to reconstruct the furnishing of this important cathedral enclosure.
\end{abstract}

\section{Key Words}

Archbishop Lope de Mendoza. Cathedral of Santiago. Tombs. Medieval Chapel. Modern Age Altarpieces. Gothic Architecture.

"Este trabajo se integra dentro del proyecto de investigación Memoria histórica de Compostela: arquitectura y urbanismo (PGIDT01PXI21003PR), financiado por la Secretaría Xeral de Investigación e Desenvolvemento da Xunta de Galicia. 


\begin{abstract}
«El terreno de la capilla de D. Lope siempre estubo en el recinto de la yglesia, asi como lo estubieron las demas piezas contiguas, y que la rodean casi por todas sus partes ó habria de presumirse que el patio arzobispal se internaba hasta la nave de la Soledad dejandose atras, y por todos lados un monton de piezas de las principales de la yglesia, comprobandose por todo que es un desvario pretender los capellanes que el terrreno o suelo de la capilla sea suyo ni lo haia podido ser jamas...».

(Pleito del cabildo con los capellanes de D. Lope. Año 1800. Archivo de la Catedral de Santiago).
\end{abstract}

$\mathrm{L}$ a capilla que el arzobispo don Lope de Mendoza dedicó a Nuestra Señora del Perdón fue la construcción gótica más importante de la basílica combispal, justo en el ángulo en el que se encuentran la nave del Evangelio de la catedral con su transepto norte ${ }^{1}$, y ocupaba, aproximadamente, el mismo solar adosado a la iglesia en el que se levantó en el siglo XVIII, una vez destruida la vieja arquitectura bajomedieval, la actual capilla de la Comunión.

Como sabemos por la inscripción que figura en el nártex de la moderna rotonda, la antigua capilla de don Lope fue concluida en el año 1451 por el cardenal Martín López ${ }^{2}$. La nueva fundación estaba asistida por seis capellanes, dos mozos

\begin{abstract}
1 «Don Lope de Mendoça fue el vigésimo sesto arçobispo de Santiago, en tiempo del rey don Juan segundo... Murió en Santiago el año mill y quatroçientos y quarenta y cinco, como consta de un letrero que está en un túmulo y sepulcro de alabastro en que está enterrado el dicho arçobispo, en medio de la capilla que llaman de Don Lope de Mendoça, que él mismo mandó edificar en un pedaço del patio del palaçio, con la puerta a la iglesia catedral, a la nave del crucero que caía haçia los palacios arçobispales» (HOYO, J. DEL, Memorias del arzobispado de Santiago, ed. de A. Rodríguez González y B. Varela Jácome. Transcripción del manuscrito original de 1607, Santiago, s.a., 23). Para tener una idea aproximada de su disposición, dimensiones y orientación, véase el plano de fray Plácido Caamiña de 1768 (Figuras 7 y 8) que, incorporado a un manuscrito de fray Bernardo Foyo, se conserva en la Biblioteca Xeral de la Universidad de Santiago. Este importante testimonio gráfico fue encontrado y estudiado recientemente por A. VIGO TRASANCOS (La Catedral de Santiago y la Ilustración, Madrid, 1999, 37-40, 124), si bien, algo errado en sus dimensiones, ya lo había reproducido anteriormente J. Ma. ZEPEDANO Y CARNERO (Historia y descripción arqueológica de la basílica compostelana, Lugo, 1870).

${ }^{2}$ La traducción del texto latino dice así: «D. Lope de Mendoza, Arzobispo de esta Santa Iglesia, mandó edificar la capilla que el Cardenal Martín López, comensal del mismo, hizo que se construyese con el producto de los frutos de la propia capilla, frutos que ella posee por el real privilegio alcanzado por dicho señor. Esta capilla fue concluida en el año del Señor 1451» (J.Mª. FERNÁNDEZ
\end{abstract}


y un sacristán, y a fin de que se terminase la construcción y se perpetuase su memoria donó el prelado un juro de treinta mil maravedíes anuales ${ }^{3}$. Con los años, la fundación de don Lope se fue configurando como un verdadero panteón familiar, pues los parientes del arzobispo siguieron dejando diversos legados para ser sepultados en la capilla. Pero también se enterraron en este recinto funerario numerosas personas ilustres de las casas de Maceda, Bendaña y Gimonde; e incluso los devotos más humildes, si dotaban adecuadamente su sepulcro, podían disponer allí su tumba. Por otra parte, los arzobispos compostelanos, como patronos y dueños de la capilla, tenían la prerrogativa de reservar las sepulturas principales de su pavimento para enterrar a sus servidores, un derecho también extensible a los propios capellanes del recinto ${ }^{4}$.

La capilla de don Lope de Mendoza, por su amplitud y magnificencia, era un auténtico espacio polivalente: fue utilizada -al menos hacia el año 1526- para custodiar las alhajas de la catedral, también en su ámbito se celebraron numerosos cabildos, y, desde 1561 hasta 1734, fue el escenario donde se celebraba solemnemente la imposición de los grados universitarios, una vez pasado el correspondiente examen que tenía lugar en la capilla de las Reliquiass.

De esta importante capilla gótica, una obra en la que el propio fundador quiso manifestar su poder y su grandeza a través de la monumentalidad de su arquitectu-

SÁNCHEZ, y F. FREIRE BARREIRO, Santiago, Jerusalén, Roma: diario de una peregrinación..., vol. I, Compostela, 1880, 87). Esta inscripción estaba colocada en la antigua capilla bajomedieval al lado del altar del Buen Jesús que, como se explicará más adelante (cfr. infra n. 60 y 62), se encontraba ubicado en el muro este de la capilla.

${ }^{3}$ «Dexó el dicho arçobispo en esta capilla seis capellanes, a los quales y a la fábrica de la dicha capilla, treinta mil maravedís de juros viejos, los quinze mil sobre alcabalas del vino desta ciudad y los otros quince mil sobre los alfolines de la sal de la villa del Padrón» (HOYO, J. DEL, op. cit., 99). En los años 1432 y 1433 el arzobispo había obtenido estos privilegios del rey don Juan II, y en 1442 consigue que el monarca acceda a destinarlos a la fundación y dotación de la capilla (LÓPEZ FERREIRO, A., Historia de la Santa A. M. Iglesia de Santiago de Compostela, vol. VII, 1904, 112). Si bien, como apuntó J. Ma . CAAMAÑO MARTÍNEZ («El arzobispo compostelano don Lope de Mendoza y sus empresas artísticas», Boletín del Seminario de Arte y Arqueología, XXVI, 1960, 34), debemos tener presente que no existe documento de fundación de la capilla, y en su testamento el prelado se limitó a encargar al cardenal Martín López su terminación.

${ }^{4}$ PÉREZ COSTANTI, P., «La capilla de don Lope en la catedral compostelana», La Patria Gallega, núms. 1, 3 y 4, correspondientes al 30 de marzo, 30 de abril y 15 de mayo de 1891; y LÓPEZ FERREIRO, A., op. cit., 114-116.

${ }^{5}$ ZEPEDANO y CARNERO, J. Ma ., Historia y descripción arqueológica..., 163-165. Debido a una serie de enfrentamientos protocolarios entre colegiales de Fonseca y canónigos de la basílica (comenzaron en agosto de 1731), dejaron de celebrarse los exámenes y la colación de grados en la catedral a partir del año 1734 . 
ra y la fastuosidad de su sepulcro ${ }^{6}$, apenas tenemos información precisa que nos permita conocer en profundidad sus características ${ }^{7}$; y aunque por el momento su conocimento exhaustivo seguirá siendo una incógnita, he tenido la fortuna de encontrar nuevos datos documentales de distinta naturaleza: descripciones, contratos, testamentos y un plano, como veremos, muy significativo, que ensamblados adecuadamente con algunas noticias dispersas -restos del naufragio de la historia que pudo rescatar en su momento Pérez Costanti, pero que hasta la fecha, que yo sepa, apenas han sido tenidas en cuenta como fuentes para el estudio de esta obra ${ }^{8}$, suponen un avance en el conocimiento histórico de esta desaparecida capilla de la catedral compostelana.

\section{LOS RETABLOS DE LA CAPILLA DE DON LOPE DE MENDOZA}

Antes de pasar a estudiar los diferentes retablos de la capilla de don Lope de Mendoza quiero hacer una aclaración: no se puede precisar con seguridad el primitivo número de altares de este recinto, pues los documentos hallados aportan datos concernientes a la Edad Moderna, y, por lo tanto, nada sabemos sobre su originaria configuración bajomedieval ${ }^{9}$. Es evidente que una vez rematada la capilla, allá por el año 1451, tenía que estar construido, o próximo a levantarse, el altar mayor: el nuevo espacio estaba dedicado a Nuestra Señora del Perdón y su imagen se tenía

\footnotetext{
${ }^{6}$ La capilla de don Lope, según CAAMAÑO MARTÍNEZ («Galicia y el Gótico», en Galicia no Tempo. 1991, Santiago, 1992, 127), se puede considerar muy próxima a las más modernas construcciones de su época, como la capilla de don Álvaro de Luna en la catedral de Toledo, la de don Alonso de Cartagena en la catedral de Burgos, o la de Anaya en la catedral vieja de Salamanca.

${ }^{7}$ Además de las escasas referencias documentales, de este antiguo recinto gótico sólo quedan las figuras esculpidas en las mochetas de la puerta izquierda del actual acceso de la capilla de la Comunión y el relieve superior en el que figura el escudo de don Lope entre dos ángeles tenantes. También pertenecen a la antigua capilla el sepulcro del cardenal Martín López, las imágenes de Nuestra Señora del Perdón y de santa Ana con la Virgen, y una serie de restos escultóricos conservados en el museo de la catedral. cfr. CAAMAÑO MARTÍNEZ, J.M ${ }^{a}$., «El arzobispo...», 40; YZQUIERDO PERRÍN R., «El Gótico», en La Catedral de Santiago de Compostela, A Coruña, 1993, 271-273, y «Virxe de Don Lope», en Cinco séculos de historia universitaria, Santiago, 1995, 238-239; BARRAL IGLESIAS, A., «E1 Museo y el Tesoro», en La catedral de Santiago de Compostela, A Coruña, 1993, 493-494.

${ }^{8}$ Sólo M. TAÍN GUZMÁN (Trazas, planos y proyectos del Archivo de la Catedral de Santiago, A Coruña, 1999, 60, 344) menciona, como veremos más adelante, dos de los varios protocolos citados por Pérez Costanti.

${ }^{9}$ Según LÓPEZ FERREIRO (op. cit., 116), la capilla gótica tenía sólo dos altares que, con el tiempo, se aumentaron a cuatro.
} 
que colocar, como no podía ser de otra forma, en el altar principal del recinto. También es muy probable que el retablo del Buen Jesús, dada la enorme devoción que el continuador de la obra, el cardenal Martín López, tenía por esta imagen, estuviese concluido por esos años ${ }^{10}$. Pero, sin embargo, se puede afirmar con plena seguridad que hacia el año 1600, un poco antes de la visita de Jerónimo del Hoyo" la capilla ya tenía cuatro retablos: el mayor, el del apóstol Tomás, el dedicado a santa Ana y el del Buen Jesús.

\section{El altar mayor}

El altar mayor de la fundación arzobispal estaba consagrado a Nuestra Señora del Perdón, la santa titular de la capilla. El plano de fray Plácido Caamiña (Figura 8), demuestra que se situaba en el lienzo norte de la estancia, un muro que lindaba con el palacio arzobispal. Sobre este altar principal se abría una «ventana» hacia el interior de la capilla, es decir, se disponía una tribuna que permitiría al prelado y a su familia asistir privadamente a las ceremonias religiosas ${ }^{12}$. Es posible que el

10 «No debemos omitir la mención de otro familiar de D. Lope, el Cardenal D. Martín López. Fue varón modelo de virtudes y muy considerado de los Arzobispos y de todo el Cabildo durante los cincuenta y dos años que fue Prebendado. Gran devoto del Dulcísimo Nombre de Jesús, con los productos de varios bienes que dejó en las vecinas parroquias de Eijo y Arines, dotó en su honor una fiesta mitrada, que debía de celebrarse el 8 de Enero de cada año» (LOPEZ FERREIRO, A., op. cit., 143). Como sabemos, la inscripción en la que figura la fecha de terminación de la capilla estaba colocada al lado del altar del Buen Jesús; incluso -como se verá en el apartado dedicado a los sepulcros de la capilla-, este cardenal tenía su monumento funerario justo al lado de este retablo. Todas estas informaciones, a pesar de no tener noticias documentales que lo confirmen, parecen indicar que este altar estaba construido ya en el siglo XV.

${ }^{11}$ En la visita de 1605 del cardenal Jerónimo del Hoyo se alude explícitamente a dos altares: el del Buen Jesús y el de santa Ana. cfr. HOYO, J. DEL, op. cit., 99-101.

${ }^{12}$ LOPEZ FERREIRO (op. cit., 116), y CAAMAÑO MARTÍNEZ («El arzobispo..., 35), mencionan la existencia de una «vidriera» sobre el altar mayor de la capilla, lo que posibilitaría oír misa desde el palacio. López Ferreiro no cita su fuente, pero Caamaño alude a un documento referente al pleito entre el cabildo y los capellanes -hoy quizás perdido ya que no figura en el legajo citado por este autor-, en el que se menciona que al construirse la nueva capilla de la Comunión «se había suprimido igualmente la ventana sobre el altar mayor, desde donde podían asistir al culto los arzobispos y sus familiares». Debo aclarar que los nuevos hallazgos documentales, en concreto las cuentas de fábrica que conservamos (sólo a partir del año 1744), recogen un pago anual dedicado a la limpieza de las vidrieras de la capilla, lo que confirma su existencia, y abre además la posibilidad de que encima del altar principal, sin duda un lugar privilegiado de la capilla, se colocasen los característicos vitrales góticos. cfr. Archivo Histórico Diocesano de Santiago (en adelante A.H.D.S.) Serie Catedral. Capilla de D. Lope. Cuentas de fábrica 1744-1824, leg. 15. Pero, a mi juicio, el pasaje citado por Caamaño no hace referencia a una «vidriera» sobre el altar mayor, sino a una «tribuna»: una ventana abierta al interior de la iglesia, es decir, un palco señorial y privado desde donde se podía asistir a la liturgia discretamente, sin ser visto. Por otro lado, no debemos confundir esta «tribuna» con el «coro alto» que, como se verá más adelante, también tenía la capilla de don Lope. Sobre esta cuestión, véase infra n. 72. 
primitivo altar principal, coetáneo a la capilla, careciese de retablo ${ }^{13}$, pero esta antigua estructura gótica fue sustituida en el año 1562 por un retablo renacentista, de «mediocre dibujo», trazado y construido por el entallador Miguel Blandón, vecino de Santiago ${ }^{14}$. Según el contrato, el artista tenía que «deshazer el retablo questa hecho en el quarto nuevo para el altar mayor de la dicha Santa yglesia» y reutilizar tres de sus hornacinas «poniendolo de la manera y orden que ocupa el hueco de los dos pilares que estan en el altar mayor de la dicha capilla de don Lopo y ha de hazer y conponer el dicho retablo que se ponga en el dicho altar mayor de la dicha capilla con las dichas tres hordenes y cajas la del medio que quepa la ymagen de nuestra señora questa en el dicho altar con su peana y los otros dos huecos quedaran para otras dos ymagenes». El retablo tendría, por lo tanto, un único cuerpo de tres calles. Una vez ensamblado, Blandón tenía que hacer un guardapolvo de cinco palmos de alto «conforme al retablo y guarda polbo de la capilla de San Sebastián» ${ }^{15}$, y además esculpir en su frontal tres serafines (Figura 1).

En diciembre de 1622, Domingo de Meri, un entallador de origen francés ${ }^{16}$, se comprometió a hacer un nuevo retablo mayor para la capilla de don Lope por

${ }^{13}$ Esta opinión fue expresada por CAAMAÑO MARTÍNEZ ( «El arzobispo...», 40), argumentando que la propia existencia de la «vidriera» sería un condicionamiento que impediría levantar un retablo. De todas formas, debemos tener en cuenta que la capilla era muy alta -el propio Caamaño (idem, 35), alude a la «alta cúpula» de crucería, y también López Ferreiro destaca su magnitud (op. cit., 116)-, y no sabemos realmente a que altura estaba situada la posible tribuna y los vitrales del recinto. De lo que no hay duda es que en el siglo XVI la capilla tenía un retablo mayor.

${ }^{14}$ Según P. PÉREZ COSTANTI (Diccionario de artistas que florecieron en Galicia durante los siglos XVI y XVII, Santiago, 1930,69), el diseño original era del propio artista y su traza estaba unida a la escritura del contrato. Desgraciadamente, a pesar de revisar todos los protocolos del notario Gonzalo de Reguera correspondientes a ese año, pues, según Costanti, fue este escribano el que dio fe del acuerdo, no logré dar con ella; pero, al menos, para tener una idea general de su configuración, nos queda la transcripción del contrato entre este entallador y don Francisco del Rego, racionero de la catedral y mayordomo de la capilla de don Lope de Mendoza (cfr. LÓPEZ FERREIRO, A. Historia..., vol. VIII, 1905, apéndice XXXVIII).

${ }^{15}$ Se refiere al desaparecido retablo gótico de la capilla del Espíritu Santo. Desde el siglo XV el gremio de los azabacheros tenía como patrón a san Sebastián y celebraba en esta capilla de la catedral sus funciones religiosas. En la actualidad se conserva una imagen de mármol de este santo, fechada alrededor de año 1448, que formaba parte del retablo bajomedieval de esta capilla. cfr. LÓPEZ FERREIRO, A., Historia..., vol. VII, 1904, 81-82. Un dibujo del guardapolvo diseñado por Miguel Blandón (Figura 1) fue reproducido y estudiado por M. TAÍN GUZMÁN (Trazas, planos..., 61).

${ }^{16}$ PÉREZ COSTANTI (Diccionario..., 376-378), así lo señala, y también aporta alguna información de su actividad artística. Entre sus obras cabe destacar un retablo de nogal que en 1618 hizo para la capilla del palacio de Fefiñanes y una caja para guardar los frontales del altar mayor de la capilla del Hospital Real en el año 1623. Pérez Costanti, sin embargo, desconocía la construcción de este tercer altar mayor de la capilla de don Lope, obra del propio Domingo de Meri. 


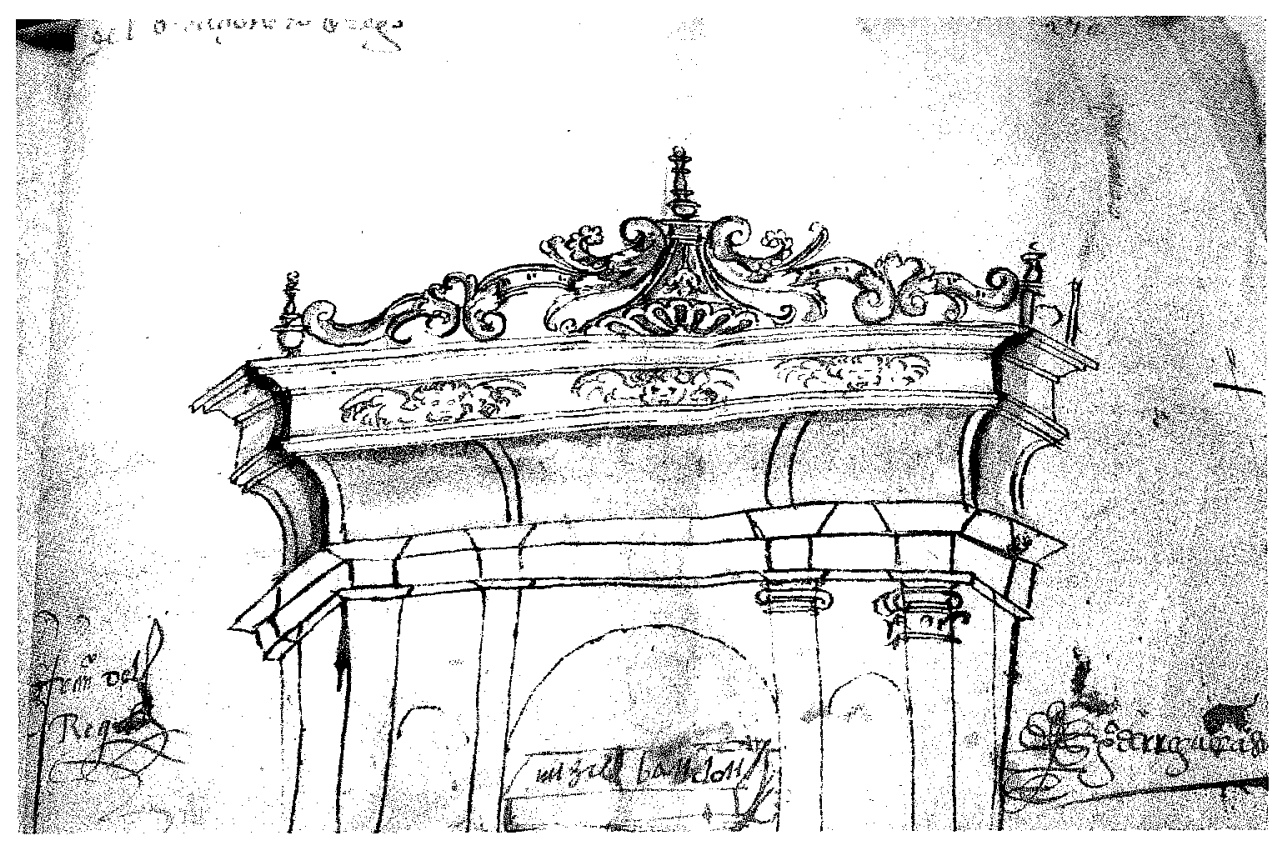

Figura 1.- Guardapolvo del retablo mayor. 1562. Miguel Blandón (A.C.S.).

2.000 reales, con arreglo a las trazas y las condiciones establecidas por dos capellanes de la fundación arzobispa ${ }^{17}$. Dieciséis años más tarde, según manifiesta un contrato fechado el 14 de abril de 1638 entre los capellanes y el pintor alemán

${ }^{17}$ Según consta en un documento concerniente al remate y condiciones del retablo mayor de la capilla hallado en el A.H.D.S. Serie Catedral. Capilla de D. Lope 1527-1868, leg. 9, s. f. En este documento se da cuenta de la decisión de los capellanes de don Lope de que «se hiciese en el altar mayor de ella un retablo». Para ello, se colocaron cédulas en la "puerta de la Quintana» y en la propia puerta de la capilla anunciando las «posturas para el remate del retablo mayor del día 28 de diciembre» del año señalado de 1622. Ese día (parescieron algunos maestros vecinos de esta ciudad de carpinteria canteria y escultores a los quales se les enseño una traça en papel que fue presentada... por su merced dicho prouisor para hacer el retablo mencionado... y se les leyo las condiciones que para lo haber de hacer tenian firmadas del dicho capellan mayor e Francisco Perez que por ellos fue visto y entendido y abiendo platicado los dichos maestros unos con otros parecio Domingo de Meri entallador e dixo que aria el dicho retablo conforme a la dicha traça e compliria las condiciones que se abian leydo dandole quatro myll reales, su merced dicho arzediano e capellanes por ser excesiba la dicha postura dixeron que no lo admitian», encendieron "una candelilla de cera» y reabrió la puja el propio Meri, quien la bajó a doscientos ducados, admitiéndosele esta postura. $\mathrm{Al}$ final, y después de intervenir otro maestro, contrató la obra del retablo el mencionado Domingo de Meri en 2.000 reales. Las condiciones también obligaban al maestro entallador a «pagar la traça a quien la uviese hecho», y conforme a ese diseño «darlo hecho y acabado dentro de un año». 
Crispín de Evelino ${ }^{18}$, su maderamen estaba en pésimo estado; por ese motivo se establece en el acuerdo que el artista «a de dar un baño de aguacola a todo el dicho retablo y figuras de manera que quede limpio», y aplicar varias manos de yeso «para que toda la carcoma de la madera quede bien encubierta» ${ }^{19}$. En esta escritura también se dispone que «todos los rostros de las ymagenes y demas encarnaciones que se dieren se an de encarnar tres beses de encarnación al temple a pulimento y mate conforme al natural, ytem que todas las colunas del dicho retablo an de yr asta el medio del perfil de oro brunido y las estrias de lo mismo y las medias canas de colores, y las cartelas y demas lavor de la fachada del retablo de oro brunido con algun lavor en medio donde lo pidiere y fuere necesario para adorno y gracia del dicho retablo, ytem que todas las cajas donde estan dichas ymaxenes y mas necesarias an de ser pintadas al olio con lauores de brocados diferentes unos de otros, ytem que la caja del crusifixo a de ser pintada con su jerusalen al olio, ytem que todos los bultos an de yr estofados de oro y colores conforme lo que cada vno representa, y la caxa de Nuestra Señora se a de pintar de oro brunido toda, y la mesa del retablo a de yr de oro limpio e brunido con algunos lavores de colores en donde fuere necesario para gracia y perfecion della $\rangle^{20}$. Como se puede deducir de las condiciones referidas, el retablo seguía presidido, según había dispuesto don Lope de Mendoza, por la patrona de la capilla, la Virgen del Perdón, que todavía hoy se conserva a la entrada de la actual capilla de la Comunión (Figura 2). Esta imagen de alabastro tardogótica, con el arzobispo arrodillado a sus pies, posee características estilísticas borgoñonas y renanas ${ }^{21}, \mathrm{y}$, sin duda, en medio de la renovada escenografía áurea y cromática del nuevo retablo, provocaba un fuerte impacto emocional en los fieles. El contrato también obligaba a Crispín de Evelino a «poner todas las pinturas ansi de oro bueno como las de yeso y mas que requieran menester las cuales an de ser vuenas y bien adresadas y an de correr por su cuenta las hestadas y todo lo demas necesario para pintar dicho retablo», y a terminar la obra para la navidad de ese año de 1638. Por su parte, el capellán mayor se comprometía a pagar al pintor 2.500 reales por su trabajo ${ }^{22}$.

${ }^{18}$ Archivo Histórico de la Universidad de Santiago (en adelante A.H.U.S.). Notario Juan Vidal. Prot. $\mathrm{n}^{\circ} 1.278$ (1638), fols. 297-298. Véase también PÉREZ COSTANTI, P., Diccionario..., 161.

${ }^{19}$ A.H.U.S., idem, fol. 297.

${ }^{20}$ A.H.U.S., ibidem.

${ }^{21}$ Según CAAMAÑO MARTÍNEZ («El arzobispo...), 39-40), la filiación borgoñona de esta escultura se evidencia en la amplitud del ropaje y la emotividad de la escena, pero en ella también se manifiesta el influjo de la región del Rhin, tanto por la expresividad de su sonrisa como por la disposición del plegado de sus paños. Véase también YZQUIERDO PERRÍN, R., «El Gotico», 273; y «Virxe de Don Lope», 238-239.

${ }^{22}$ A.H.U.S., idem, fols. $297-297$ v. 


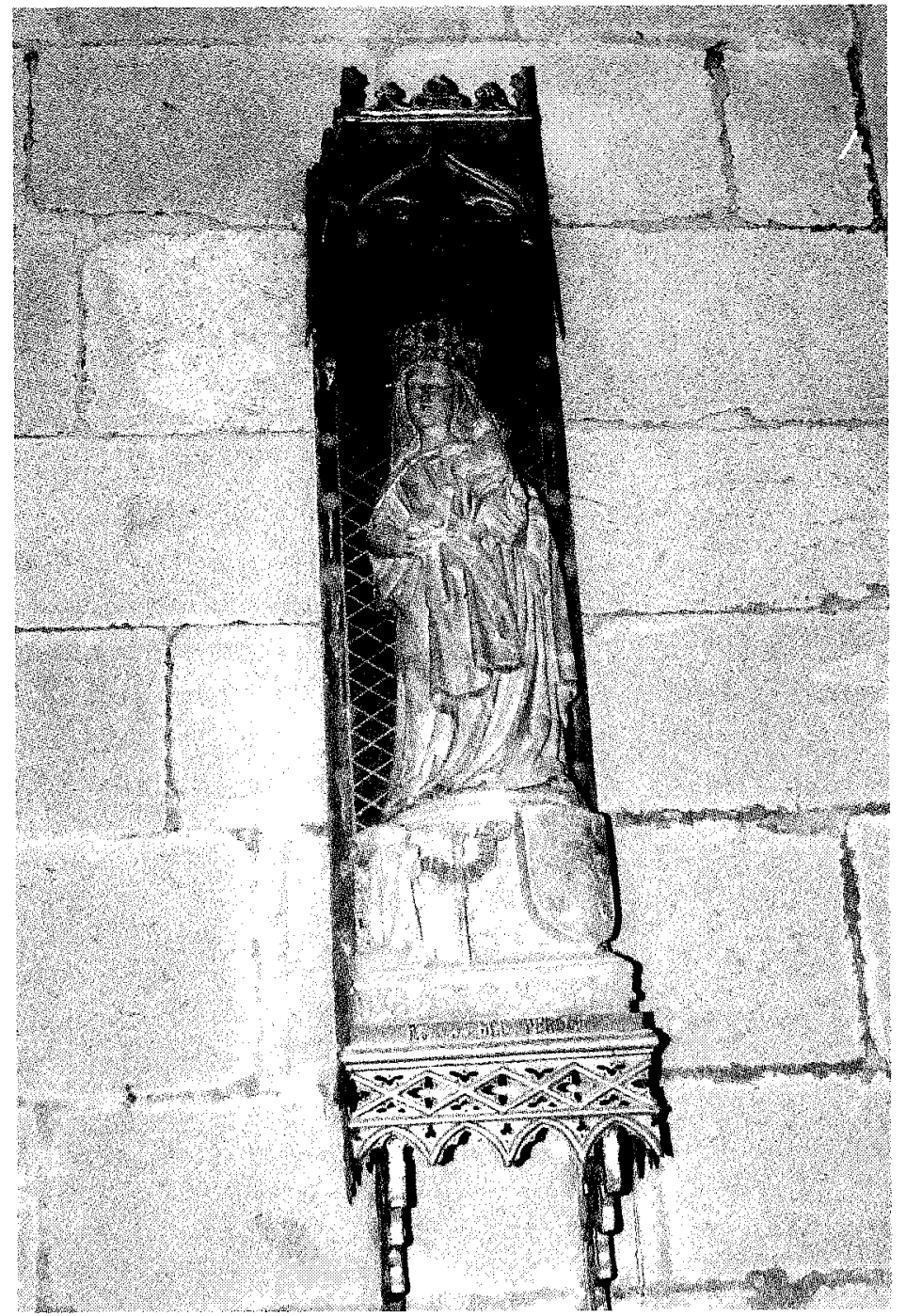

Figura 2.- Nuestra Señora del Perdón.

En el año 1605, como sabemos, el cardenal Jerónimo del Hoyo visitó la capilla de don Lope de Mendoza, dejándonos en su manuscrito algunas informaciones esenciales para conocer sus características; será otro visitador general del arzobispado, don Ramón Bernardo Pillado, el que contribuirá - esta vez a través de una relación notarial que recoge su visita del día 15 de agosto de 1767 , pocos meses antes de emprenderse las obras de demolición de este antiguo recinto gótico-, a 
que conozcamos un poco mejor este singular ámbito de la catedral compostelana ${ }^{23}$. Según este importante documento, el retablo mayor que tenía la estancia bajomedieval en esa fecha se organizaba en dos cuerpos estructurados en tres calles, y un ático. En la hornacina central del primer piso, como establecía la propia advocación de la capilla, se disponía la imagen de la santa titular del recinto, $\mathrm{y}$, a sus lados, en los nichos contiguos, las efigies de san Liborio y san Jerónimo. En el segundo cuerpo estaba ubicada la escultura de Nuestra Señora de la Angustia, en su calle media, acompañada por las imágenes de san Francisco y san Antonio, que ocupaban, a su vez, los huecos laterales. Culminaba la obra la figura de un crucificado, que, instalado en el ático del retablo, estaba flanqueado por dos escudos del arzobispo don Lope de Mendoza ${ }^{24}$.

En definitiva, se puede afirmar que a lo largo de los 317 años que perduró la capilla bajomedieval ${ }^{25}$ se construyeron, por lo menos, tres altares principales: uno gótico a mediados del siglo XV, otro de estilo renacentista en el año 1562, y un último retablo levantado hacia 1623. A pesar de todas las limitaciones que establece la fragmentación de los datos, pienso que es probable que el retablo mayor que se describe en la visita de 1767 sea el mismo que en el año 1622 contrató Domingo de Meri. Entiendo ésto por dos razones fundamentales: la clara alusión a la anti-

${ }^{23}$ Por fortuna, he podido encontrar una descripción de los cuatro retablos de la capilla en un documento fechado en agosto de 1767 que recoge la visita a este desaparecido recinto medieval de don Ramón Bernardo Pillado, juez eclesiástico del arzobispado y visitador general del arzobispo Rajoy. Este testimonio se encuentra en el A.H.D.S. Serie Catedral. Capilla de D. Lope 1527-1868, leg. 9, Autos obrados por el señor Doctor Don Ramon Bernardo Pillado..., s. f. En los cabildos celebrados en la capilla también se recoge esta visita, pero de forma más sucinta (A.H.D.S. Serie Catedral. Capilla de D. Lope. Autos capitulares 1740-1828, leg. 14, fols. 69-70).

24 «...y hauiendo entrado hallo el altar maior con la ymagen de marmol aduocazion de nuestra señora del Perdon, y de colacterales la de san Liborio y San Geronimo, en el segundo cuerpo de dicho altar la ymagen de Nuestra señora de la Angustia y a los lados san Francisco y san Antonio y en el remate un santisimo Christo y los escudos del Ylmo. señor fundador a los lados, la mesa del altar con frontal de madera pintado piedra de ara, calix y patena de plata todo sobredorado, bolsa de Corporales, cruz de bronze, Misal, atril, y dos candeleros de bronze y dos misarios que se asento eran puestos por el cauildo de esa santa yglesia y tambien las alaxas» (A.H.D.S. Serie Catedral. Capilla de D. Lope 1527-1868, leg. 9, Autos obrados..., s. f.).

${ }^{25}$ La capilla de don Lope, como sabemos, se termina en el año 1451. La primer etapa de la construcción de la nueva capilla de la Comunión se inicia en abril de 1768, fecha en la que comenzaron los trabajos de derribo de la antigua capilla de don Lope de Mendoza. $c f r$ VIGO TRASANCOS, A., «Domingo Lois Monteagudo y la capilla de la Comunión de la catedral compostelana (17641783)», Boletín del Seminario de Estudios de Arte y Arqueologia, LV, 1989, 454; y La catedral..., 106. 
güedad de esta obra en la relación notarial de la visita ${ }^{26}$, y las posibles coincidencias en la temática del ático's?.

\section{El altar de santo Tomás}

La cofradía gremial de santo Tomé, constituida por los carpinteros y canteros de la ciudad ${ }^{28}$, tenía en la capilla de don Lope un retablo dedicado a este apóstol. Se conserva un contrato fechado el 7 de abril de 1600 entre el carpintero mayor de la cofradía y Carlos de $\mathrm{Meri}^{29}$, un entallador extranjero que desarrolló su actividad artística en Compostela durante las primeras décadas de seiscientos ${ }^{30}$. Cosidas a la escritura notarial figuran las trazas del altar proyectado por la congregación, un valioso testimonio gráfico que nos permite conocer sus características generales (Figura 6). No cabe duda de que el dibujo es una mera guía y la obra sufriría probablemente diversas modificaciones en su proceso de realización, pero es útil

\footnotetext{
${ }^{26}$ Cuando se pasa a describir el primer retablo colateral, el del apóstol Tomás, se afirma que es «de madera y tanbien biejo», como el anteriormente descrito, el altar principal, con el que comienza la descripción de la capilla. Al respecto, véase infra n. 33 .

${ }^{27}$ En el contrato con Crispín de Evelino para pintar el retablo de Domingo de Meri se acuerda que la «caja del crusifixo a de ser pintada con su jerusalen al olio»; es decir, el fondo de la hornacina tenía un relieve o una pintura que representaba la ciudad de Jerusalén, y sobre él se disponía un Cristo, lo que parece coincidir con la alusión al «santisimo Christo» que, según la descripción de 1767, coronaba el retablo mayor, dispuesto en medio de los dos escudos del fundador de la capilla.

${ }^{28}$ La cofradía de santo Tomé, constituida por canteros, carpinteros, entalladores, arquitectos, escultores, etc., existía como gremio desde el siglo XIV. cfr. FERNÁNDEZ ÁLVAREZ, Ma ${ }^{\mathrm{a}}$.A., Arte y sociedad en Compostela 1660-1710, Sada, 1996, 142.

${ }^{29}$ A.H.U.S. Notario Pedro Seixas. Prot. $n^{\circ} 687$ (1600), fols. 539-540. El dibujo está cosido al fol. 541 (Agradezco a $\mathrm{M}^{\mathrm{a}}$ José Justo Martín, directora del Archivo Histórico de la Universidad, todas las facilidades que, amablemente, me dispensó a la hora de fotografíar esta traza que ahora presento). Debajo del diseño figura escrita la siguiente anotación: «Esta es la traça del retablo que se a hazer para la Capilla de la Cofradia de Santo Thome en preçio de treinta y quatro ducados tiene catorze palmos de ancho y de alto todo lo que quisiere», lo que documenta, de nuevo, la enorme altura de la capilla. El acuerdo tiene fecha de 7 de abril de 1600, y se lleva a cabo entre «Alonso de Beade, carpintero mayor de la cofradía del Señor Santo Tomé ynclusa en la capilla de don Lope de la Santa Yglesia de Santiago y de la otra Carlos de Meri entallador bezino de la dicha ciudad». Las condiciones que se establecen son los ya referidos «14 palmos de ancho», y de alto «todo lo que quiera subir Carlos de Meri». Conforme a la traza, el maestro entallador tiene que «poner la madera de nogal a su costa y entiende que el dicho retablo no ha de tener mas de cuatro columnas y ha de tener orden corintia con pilares y traspilares y capiteles en las columnas y cimeras». La existencia de esta escritura ya fue apuntada con anterioridad por P. PÉREZ COSTANTI (Diccionario..., 376378). Por su parte, M. TAÍN GUZMÁN (Trazas, planos..., 344-345) descubrió en el archivo de la catedral una copia anónima de este proyecto de Meri. Este duplicado lleva además un texto del propio Pérez Costanti mencionando el protocolo notarial arriba citado.

${ }^{30}$ PÉREZ COSTANTI, P., Diccionario..., 376-378.
} 
para tener una idea aproximada de sus formas. Se trataba de un retablo construido en madera de nogal y de estilo renacentista. Elevado sobre un banco, consta de un cuerpo dividido en tres calles por cuatro columnas corintias y un ático. Su sencilla estructura arquitectónica mantiene un criterio clásico en su articulación vertical, sin profundidad en las hornacinas, y con un entablamento, como corresponde al estilo, rígido e inerte. El ático se ve animado levemente por la moldura alta del frontón triangular, los secos ornatos fitomórficos -bien diferentes de las jugosas tallas vegetales del futuro barroco gallego-, y las volutas de los aletones que integran los dos cuerpos del retablo. En el año 1603, el escultor Pedro de Bran contrata «un sobre cuerpo con un Dios Padre por remate» para este mismo retablo ${ }^{31}$.

La visita mencionada de don Ramón Pillado también aporta nuevos datos complementarios, y si tenemos en cuenta los paralelismos con el diseño y la referencia explícita de su antigüedad es posible que este retablo construido por Carlos de Meri tampoco se renovase posteriormente ${ }^{32}$. El altar de santo Tomás descrito en agosto de 1767 tenía, al igual que el trazado en el año 1600, un solo cuerpo y un ático. En su hornacina central estaría colocada la imagen del apóstol Tomás, con Santiago y san José ocupando los nichos de las calles laterales. En el ático se disponía «la ymajen de Nuestra Señora de la Concepcion» ${ }^{33}$.

\section{El altar de Santa Ana}

El siguiente retablo que se describe en la visita de 1767 estaba dedicado a santa Ana «con Nuestra Señora en los brazos» ${ }^{34}$, lo que confirma documentalmente la

\footnotetext{
${ }^{31}$ op. cit., 67.

${ }^{32}$ Un dato que, en parte, refuerza la hipótesis apuntada de que estos dos retablos de la capilla de don Lope (el mayor y el de santo Tomás) no se renovaron desde las primeras décadas del siglo XVII en que fueron construidos es la preocupación del propio cabildo de la catedral por la falta de decoro de los retablos de esta capilla. En cabildo de 20 de noviembre de 1739 se acuerda «que en la contaduría se bea la obligación de hornatos y mas de los capellanes de D. Lope y se traiga al cauildo para resolver sobre la yndecencia de los altares de dicha capilla» (Archivo de la Catedral de Santiago (en adelante A.C.S.). Actas capitulares 1734-1739, leg. 521, fol. 339). De todas formas, mientras no se descubran nuevos datos al respecto, no se puede afirmar con seguridad la permanencia de las viejas estructuras hasta agosto de 1767.

${ }^{33}$ «Y tambien halló otros tres colacterales uno de santo Thome, de madera y tanbien biejo en el primer tramo de el se alla la ymajen del Apostol santo Thomas, a los lados la del Apostol señor Santiago y la del patriarca señor don Joseph= y en el segundo tramo la ymajen de Nuestra señora de la Concepcion: la mesa del altar, com mesa de manteles de lienzo mediana, calix y patena de plata esta sobredorada, bolsa de corporales mui husada: misal con atril de madera, dos candeleros y una cruz de bronze, e piedra de ara, frontal de madera pintadon (A.H.D.S. Serie Catedral. Capilla de D. Lope 1527-1868, leg. 9, Autos obrados..., s. f.).

${ }^{34}$ Véase infra n. 41.
} 


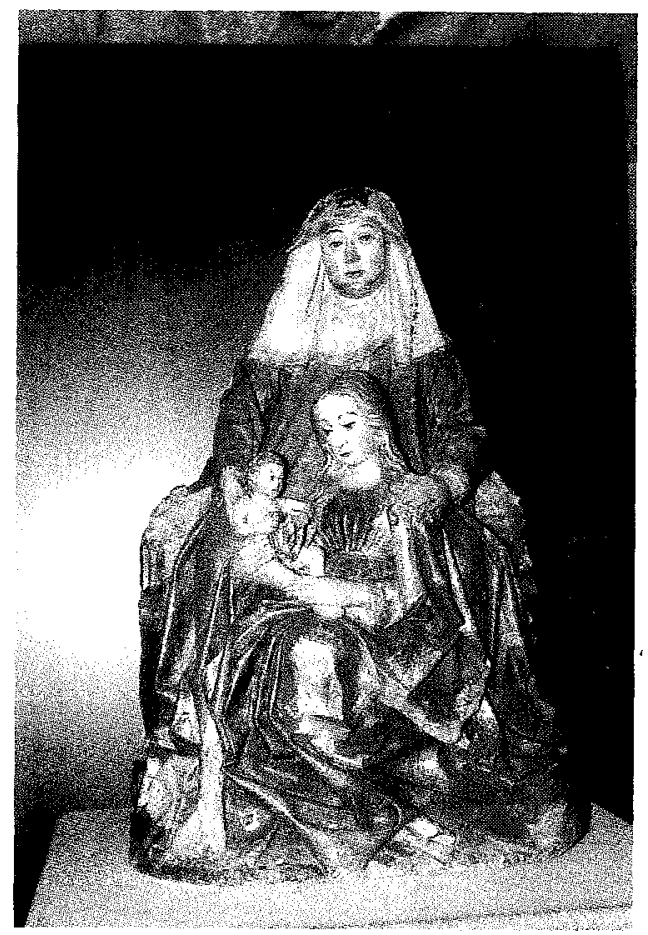

Figura 3.- Santa Ana con la Virgen y el Niño.

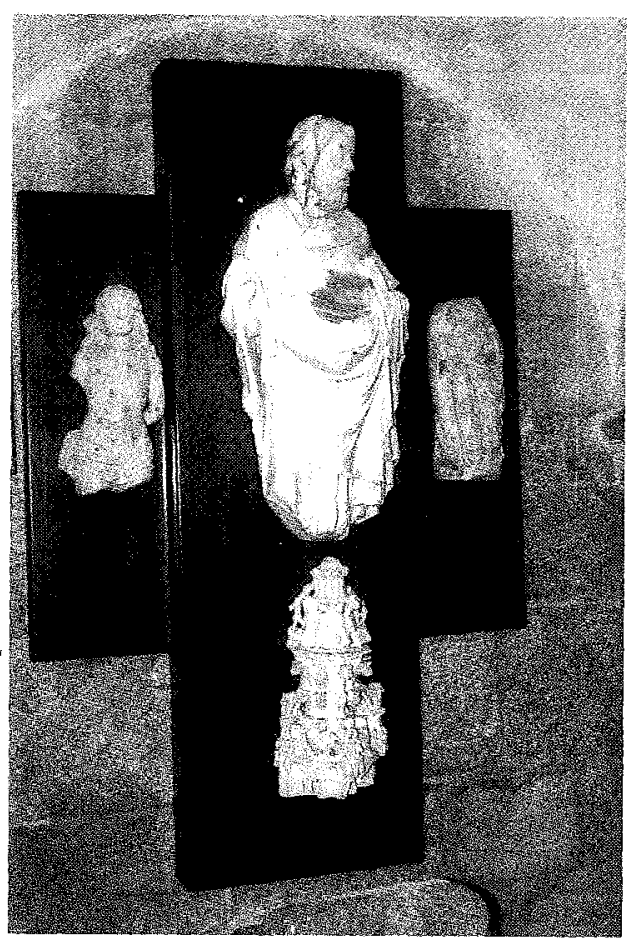

Figura 4.- Restos escultóricos de la capilla de don Lope.

tradicional filiación del grupo escultórico conservado en el museo de la catedral ${ }^{35}$ (Figura 3).

El cardenal Jerónimo del Hoyo también había mencionado en su manuscrito que «Frutuoso da Fonte, racionero que fue desta Sancta Iglesia dejó en la capilla el retablo y altar de Señora Sancta Ana» ${ }^{36}$, y ahora, a la vista de las nuevas informaciones halladas, se puede precisar que el 8 de octubre de 1591 este racionero del Sancti Spiritus instituyó una dotación perpetua de dos sepulturas «cerca donde estan las sepulturas de los Patiños a la mano derecha de la Epistola», solicitando

${ }^{35}$ J. DEL HOYO (op. cit., 100, 101), ya había mencionado la existencia de un altar dedicado a santa Ana en la capilla, un dato que fue utilizado por A. LÓPEZ FERREIRO (Galicia en el último tercio del siglo $X \mathrm{~V}$, Vigo, 1968 [1“ ed., A Coruña, 1896-97], 260), para establecer acertadamente la procedencia de esta imagen. Al respecto, véase también R. YZQUIERDO PERRÍN ( Groticom..., 273).

${ }^{36}$ HOYO, J. DEL, op. cit., 101. 
además permiso para levantar un nuevo retablo en el altar dedicado a santa $\mathrm{Ana}^{37}$, una referencia que demuestra la existencia de un altar precedente consagrado a la madre de la Virgen.

Según el auto notarial que recoge la visita de don Ramón Pillado, el retablo era una construcción de tres cuerpos. Su nivel inferior estaba dividido en cinco calles, con la imagen de santa Ana en su hornacina central y las esculturas de los apóstoles Pedro ${ }^{38}$, Santiago, Juan y Pablo en los respectivos nichos laterales. En el tramo medio del retablo, articulado a su vez en tres calles, se disponía, en su hueco central «la efigie de un santisimo Christo questa en la cruz y a los pies de ella la Madalena», y en las hornacinas de los lados «Nuestra Señora de la Concepcion» y san Fructuoso ${ }^{39}$. Coronaban el retablo «dos hornitas pequeñas» con las imágenes de san Francisco y otra "que no se distingue» ${ }^{40}$. La mesa de altar, como en los demás retablos de la capilla, tenía su frontal de madera pintado ${ }^{41}$.

${ }^{37}$ «En ocho de octubre del año de 1591 por ante mi Domingo Cabaleleiro escribano del cabildo, el racionero Frutuoso da Fonte doto dos sepolturas en la capilla de Don Lope y pidio a los capellanes el altar de la señora Santana para en el poner un retablo ymajenes y aser decir en el las misas i oficios que le pareciesen señalando para la dotacion de dichas sepolturas y perpectuidad del retablo el lugar que tenia en la felegresia de Santiago de Boado» (A.H.D.S. Serie Catedral. Capilla de D. Lope 1527-1868, leg. 9, s. f.). También se conserva en este mismo legajo una copia de la fundación del racionero, y en ella se especifica el lugar de enterramiento arriba citado, situado en el muro de la Epistola.

${ }^{38}$ Probablemente, la erosionada escultura de alabastro policromado de san Pedro que se conserva en el museo de la catedral estaba colocada en este retablo (Figura 4). Véase infra n. 40.

${ }^{39}$ No es de extrañar que el patrocinador, el racionero Fructuoso da Fonte, colocase la imagen de su santo patrón en el nuevo retablo.

${ }^{40}$ Es posible que esta imagen desconocida corresponda a santa Lucía o a san Sebastián, dos esculturas que se conservan también en el museo catedralicio, y que proceden de la capilla de don Lope (Figura 4). Sobre estos restos escultóricos y la anteriormente mencionada imagen de san Pedro, véase BARRAL IGLESIAS, A., «E1 Museo...», 493-494.

${ }^{41}$ «El tercero, colectoral, en el primer tramo se alla la ymajen de santa Ana con nuestra señora en los brazos; a los lados quatro efigies de los apostoles, san Pedro, Santiago, san Juan y san Pablo; en el segundo tramo la efigie de un santissimo Christo questa en la cruz y a los pies de ella la Madalena; a los lados Nuestra señora de la Concepcion y san Fructuoso, y enzima de el un letrero... el tercero tramo se compone de dos hornitas pequeñas y en ellas se allan los santos el uno al parezer san Francisco y el otro no se distingue, todo biejo como tanuien lo esta el segundo colectoral: la mesa del altar tiene frontal de madera pintado. Piedra ara mesa de manteles de lienzo, husado; caliz y patena de plata sobredorado bolza de corporales, misal con atril de madera; este tercero colectoral tiene lampara de plata con cubierta de lo mismo mediana» (A.H.D.S. Serie Catedral. Capilla de D. Lope 1527-1868, leg. 9, Autos obrados..., s. f.). 


\section{El altar del Buen Jesús}

Como se ha explicado anteriormente, es casi seguro que el primer retablo dedicado al Buen Jesús fuese levantado al construirse la capilla a mediados del siglo $\mathrm{XV}^{42}$; pero, en realidad, nada conocemos sobre su primitiva configuración, y casi todas las noticias que logré reunir sobre esta obra corresponden al setecientos. De todas formas -y como digo sin poder precisar si fue renovado o por el contrario se mantenía en pie el originario altar gótico-, este retablo se encontraba en el año 1663 en tan mal estado que los capellanes manifiestan a la cofradía de los carpinteros de la ciudad que lo atendía su falta de decoro. Casi un siglo más tarde, en agosto de 1748 , los cofrades por fin se deciden a construir un nuevo retablo ${ }^{43}$. Según el proyecto de la hermandad de san José $e^{44}$, la nueva estructura tendría una organización similar a la que articula el retablo de santo Tomás. Por consiguiente, su primer cuerpo estaría estructurado por tres calles, la central presidida por la imagen de san José, el patrón de la congregación, reservando los nichos laterales para una escultura de la Virgen de la Soledad y otra figura escogida por los capellanes. En el ático del retablo se instalaría la imagen del «santísimo Cristo del Buen Jesús». La propuesta también incluía unos cajones para guardar la cera de la cofradía.

La reedificación del retablo del Buen Jesús planeada por la hermandad finalmente no se llevó a cabo, posiblemente por algún problema relacionado con su planta ${ }^{45}$,

${ }^{42}$ cfr. supra n. 10 y 11.

${ }^{43}$ El 11 de agosto de 1748 es estudiada la solicitud de la cofradía por los capellanes de don Lope. He aquí lo que pedían los cofrades: «Señores capellanes de la capilla del Ilmo. señor D. Lope de Mendoza= El Mayordomo y cofrades del Glorioso Patriarca Señor San Joseph cuia cofradia esta colocada en esta capilla representan a Vuestras Mercedes que reconociendo lo poco dezente del altar de Buen Jesús en que esta el glorioso santo por señalamiento que hicieron a la cofradia en el año pasado de mil seiscientos sesenta y tres los señores capellanes sus antecesores y movidos del zelo y deuocion al santo tienen determinado reedificar dicho altar haciendo un nueuo retablo con la ymagen del glorioso santo, y poner encima de ella la del santisimo Christo, de el Buen Jesús y a la derecha del santo la de Nuestra señora de la Soledad, que esta en dicho altar, y al lado yzquierdo la que fuese del agrado de Vuestras Mercedes poniendo frontal y manteles a dicho altar, y hazer deuajo de el unos cajones para recoger la zera de la cofradia en que no contemplan se siga perjuicio ni embarazo alguno a la capilla, antes bien se hermosea, y pone mas dezente el culto diuino por lo que suplican a Vuestras Mercedes, se siruan darles lizencia y facultad para dicha fabrica que en ello haran un gran obsequio al santo y a los suplicantes...» (A.H.D.S. Serie Catedral. Capilla de D. Lope. Autos capitulares 1740-1828, leg. 14, fols. 26 v.-27).

${ }^{44}$ La cofradía de san José surge a mediados del siglo XVII como asociación piadosa. cfr. FERNÁNDEZ ÁLVAREZ, Ma. A., Arte y sociedad..., 142.

${ }^{45}$ De nuevo, el 3 de enero de 1749 , los cofrades de san José «boluieron a pedir... se les diese lizencia para hacer el altar a dicho santo presentando las capitulaciones echas por el señor Luaces y fue acordado que haciendolo ellos de la planta de dicho retablo se les permitiria, y no de otra manera» (A.H.D.S. Serie Catedral. Capilla de D. Lope. Autos capitulares 1740-1828, leg. 14, fol. 27 v.). 
pues, según la visita de 1767 , «el quarto y ultimo colectoral se alla con su mesa de altar frontal asimismo de madera pintado, sin piedra de ara, mesa de manteles ni otra cosa alguna, y asentaron los cinco capellanes que asisten a la presente bisita no celebrarse en el el santo sacrificio de la misa, a excepcion de una cada año, el dia del santo nombre de Jesus y en el tramo de que se compone se alla la efigie de un santisimo Christo y al pie de la cruz la de la Madalena, a los lados la de Nuestra señora de los Dolores y san Juan, en una hurna que tiene su rejilla de hierro Nuestra señora de la Soledad con manto de tafetan biejo ${ }^{46}$. Como vemos, el retablo descrito en la visita de don Ramón Pillado sólo tenía un cuerpo, y carecía, por lo tanto, del ático proyectado. Tampoco se fabricaron los cajones para recoger la cera de la cofradia $a^{47}$ i los manteles de la mesa del altar ${ }^{48}$. Por el contrario, el frontal de madera para el altar fue renovado y también se pintó, pero por cuenta de la fundación arzobispal ${ }^{49}$, y no a cargo de la hermandad. Un dato muy significativo del posible mal entendimiento entre capellanes y cofrades es que en la mencionada visita de Pillado no se hace referencia a la imagen de san José, lo que parece indicar que en algún momento entre 1749 y 1767, por algún motivo que desconocemos, esta escultura fue trasladada del retablo y se dejaron de celebrar en el altar las preceptivas ceremonias de la cofradía ${ }^{50}$.

${ }^{46}$ A.H.D.S. Serie Catedral. Capilla de D. Lope $1527-1868$, leg. 9, Autos obrados..., s. f. Este retablo estaba situado en el muro este de la capilla. cfr. infra n. 60 .

${ }^{47}$ Al no llevarse a cabo la obra proyectada, seguramente los cofrades seguían utilizando el antiguo arcón colocado debajo de la escalera que subía al coro de la capilla, como documenta una escritura otorgada el 28 de mayo de 1685 por los capellanes de don Lope a la referida cofradía de san José. Para no alargar las referencias me limito a extractar la parte más significativa de dicho acuerdo, que dice así: «y los dichos capellanes consienten que la dicha cofradia tenga y ponga en dicha capilla deuajo de la escalera por donde se sube al coro della desde oy dia para siempre xamas dicha arca donde recoger la zera y mas cosas que cupieren dentro de ella» (A.H.U.S. Notario Juan Martínez de Cea. Prot. $n^{\circ} 1411$ (1685), fols. 38-39).

${ }^{48} \mathrm{De}$ hecho, en la visita se indica explícitamente que este altar no tenía «piedra de ara, mesa de manteles ni otra cosa alguna»; es más, los propios capellanes reconocen que en este altar sólo se celebra la misa el «dia del santo nombre de Jesus», al que está dedicado el retablo (A.H.D.S. Serie Catedral. Capilla de D. Lope 1527-1868, leg. 9, Autos obrados..., s. f.).

${ }^{49}$ En el cabildo 19 enero 1750 se acuerda que «se hiziese un frontal de madera para el altar del Buen Jesús cuio frontal se pintase» (A.H.D.S. Serie Catedral. Capilla de D. Lope. Autos capitulares 1740-1828, leg. 14, fol. 29 v.). Esta obra tuvo un coste de 260 reales: «Ytem 260 reales de vellon que tubo de coste el frontal con su marco todo de madera, para el altar del Buen Jesús y despues el pintarlo» (A.H.D.S. Serie catedral. Capilla de D. Lope. Cuentas de fábrica 1744-1824, leg. 15, fol. $21 \mathrm{v}$.$) .$

${ }^{50}$ No olvidemos que en este altar, según reconocen los propios capellanes durante la visita de don Ramón Pillado, sólo se celebraban los oficios religiosos el día del Buen Jesús. Véase supra n. 48. 
La capilla también disponía del mobiliario necesario para guardar los vestidos litúrgicos y los diferentes elementos usados en las funciones religiosas ${ }^{51}$.

Y por último, a pesar de no formar parte de la historia de la desaparecida capilla de don Lope de Mendoza, sólo resta añadir la descripción de los retablos que se colocaron en los intercolumnios de la capilla de Comunión hacia el año $1783^{52}$, una vez terminada la nueva rotonda ilustrada de Domingo Lois Monteagudo y Miguel Ferro Caaveiro: «En el del Norte que es el mayor, está el Sagrario y se venera un devoto Crucifijo en medio de la Virgen y de S. Juan. La imagen de Santa María Salomé, que se ve en el tabernáculo, y la Sagrada Familia huyendo á Egipto y regresando de aquel desierto, en las gradas y bajo fanales, completan el adorno de este altar... En el altar del Este, dedicado á S. Blas, hay una urna de cristal, con la imagen y reliquias de Santa Filomena. El del Oeste está consagrado á Nuestra Señora de las Angustias $)^{53}$. Estos retablos, a pesar de las protestas de los capellanes de don Lope, permanecieron en la cápilla de la Comunión hasta que López Ferreiro decidió realizar una serie de intervenciones historicistas en el recinto a fin de incrementar su neoclasicismo ${ }^{54}$.

\footnotetext{
${ }^{51}$ "Hallose un cajon de madera usado con tres diuisiones y en el ultmo siete casullas de seda de barios colores medianas quatro albas de lienzo usadas quatro amitos, dos zingulos de seda un calix y patena de plata sobredorado dos binajeras de lo mismo sin tapa... y que lo que se hallo en los otros dos cajones, que son casullas albas y amitos, son del cauildo de dicha Santa Yglesia quien pone dichos dos misarios en cumplimiento de una fundacion echa en dicha capilla por D. Juan de Sanclemente arzobispo y señor que ha sido de este arzobispado... hallose tambien una tabla con papel escritas las misas que a cada capellan corresponden en el mes pasado de julio firmada de dicho D. Seuastian de Castro» (A.H.D.S. Serie Catedral. Capilla de D. Lope 1527-1868, leg. 9, Autos obrados..., s. f.).

${ }^{52}$ A tenor de un poder otorgado por los capellanes de don Lope el 8 de marzo de 1784 para iniciar el pleito contra el cabildo (A.H.U.S. Notario R. Paz de Ponte y Andrade. Prot. $\mathrm{n}^{\circ} 7.260$ (1784), fols. 14-17v.), comprobamos que estos retablos, que desde luego, como es evidente, nada tienen que ver con los dispuestos en la capilla bajomedieval, ya estaban levantados al rematarse la nueva capilla. Entre las múltiples quejas de los capellanes ante la nueva construcción, se denuncia que «se pusieron en ella solamente tres altares hauiendo antes quatro precisos para algunas fundaciones; se separo del principal la debota imagen de Nuestra Señora del Perdon Patrona, y a cuia advocacion la ha fundado dicho IIm. Señor D. Lope de Mendoza, colocando en su lugar otra diuersa ymagen, cuio Patronato y advocacion se quiere substituir» (fol. 16). Más adelante nos enteramos que esa imagen era la de María Salomé: «se colocasen en ella los quatro altares que antes tenia... y en el principal, la debota ymagen de Nuestra Señora del Perdon, su berdadera Patrona, separando la de santa Maria Salomé como se deue» (fol. 16 v.).

${ }^{53}$ J.M ${ }^{\mathrm{a}}$. FERNÁNDEZ SÁNCHEZ y F. FREIRE BARREIRO, op. cit., 88.

${ }^{54}$ Para conocer las alteraciones historicistas llevadas a cabo por López Ferreiro entre los años 1895-1907, véase VIGO TRASANCOS, A., La catedral..., 100, 110.
} 


\section{ALGUNOS SEPULCROS DE LA CAPILLA: LOS MONUMENTOS FUNERARIOS DEL ARZOBISPO DON LOPE DE MENDOZA, DEL CARDENAL MARTÍN LÓPEZ Y DEL REGIDOR PEDRO SISO}

La capilla de don Lope tenía numerosas sepulturas incrustadas en sus muros y en el suelo del recinto de las que sólo conocemos el nombre del difunto ${ }^{55}$, por ese motivo, en este apartado del trabajo me limitaré a hacer referencia a los tres sepulcros más significativos, de los que, en definitiva, tenemos noticias más precisas.

Sin duda, el monumento más importante de la vieja capilla funeraria de Nuestra Señora del Perdón era el de su comitente, el arzobispo don Lope de Mendoza, que construyó esta fastuosa estancia gótica con el deseo expreso de perpetuar su memoria y la de su familia. Jerónimo del Hoyo describe su espléndido mausoleo como una construcción de «alabastro muy grande y muy bien labrado. Y ensima deste sepulcro está de bulto el dicho arçobispo del mismo alabastro todo muy bien labrado y demás de tener el dicho sepulcro muchas figuras de bulto del mismo alabastro labrado está asentado sobre dos leones del mismo alabastro ${ }^{56}$. El monumento funerario del prelado estaba situado en el centro del recinto, con los familiares y allegados en torno ${ }^{57}$, pero una vez decidida la construcción de la nueva capilla de la Comunión, como embarazaba su funcionalidad espacial, el arzobispo Rajoy, de acuerdo con el cabildo, decide trasladarlo de su primitiva ubicación ${ }^{58}$.

${ }^{55}$ En la última parte del documento que recoge la visita de 1767 de don Bernardo Pillado, dedicada precisamente a las fundaciones de la capilla, figura un listado en el que se mencionan algunas sepulturas de capellanes, de varios devotos de las cofradías de san José y santo Tomás, y de otros personajes. cfr. A.H.D.S. Serie Catedral. Capilla de D. Lope 1527-1868, Autos obrados... leg. 9, s. f.

${ }^{56}$ HOYO, J. DEL, op. cit., 99. El cardenal también transcribe la inscripción latina que tenía el sepulcro arzobispal. Su traducción es la siguiente: «En este sepulcro yace el cuerpo del Reverendisimo D. Lope de Mendoza, Doctor en Leyes, Arzobispo Compostelano, que durmió en el Señor el día 3 del mes de febrero del año del Señor 1445» (J. Ma . FERNÁNDEZ SÁNCHEZ y F. FREIRE BARREIRO, op. cit, 87). Para conocer las divergencias en las noticias transmitidas respecto al número de leones que sostenían el sepulcro de don Lope, véase J. $\mathrm{M}^{\mathrm{a}}$. CAAMAÑO MARTínEZ («El arzobispo...», 38)

${ }^{57}$ Esta disposición central de la tumba del fundador responde al tipo de capilla funeraria octogonal aparecida a fines del siglo XIII. A pesar de que la capilla de don Lope era de planta rectangular, mantenía una ordenación semejante, y, en este sentido, se puede comparar con la capilla de Gil de Albornoz, en la girola de la catedral de Toledo (CAAMAÑO MARTÍNEZ, J. Mª, «El arzobispo...», 37). También apuntó este autor algunas coincidencias con la capilla del Maestre de Calatrava don Pedro Girón.

${ }^{98}$ A. VIGO TRASANCOS (La catedral..., 95); y F. SINGUL LORENZO (La ciudad de las luces. Arquitectura y urbanismo en Santiago de Compostela durante la Ilustración, Santiago, 2001, 199-200). Sobre los distintos emplazamientos del panteón arzobispal, véase J. M. CAAMAÑO MARTÍNEZ («El arzobispo...», 41-43). 
La visita de agosto de 1767 aporta escasas informaciones -confirma, eso sí, que tanto este mausoleo como los demás monumentos permanecían todavía en la capilla en esa fecha, pocos meses antes de comenzar su demolición-, y hasta que no se encuentren referencias más concretas sus características seguirán siendo un enigma. Del sepulcro del fundador sólo se menciona que hay «en medio del terreno de dicha capilla un panteon de alabastro y enzima de el el retrato de dicho señor D. Lope de Mendoza, a los lados de el dos lapidas de piedra enteras y en ellas dos retratos que no se perciben y asertaron los referidos cinco capellanes serbian las dos sepolturas hallandose desocuadas para darse quando muere alguno de ellos $\rangle^{59}$. Como no podía ser de otra forma, la tumba que acogía los restos del fundador seguía marcando a mediados del siglo XVIII la etiqueta de las exequias de la capilla y los capellanes reservaban lugares de enterramiento próximos al panteón del arzobispo.

También estaba enterrado en la capilla el cardenal Martín López, pero su sepulcro, al contrario de lo que se creía, estaba situado en el muro este de la capilla, justo al lado del retablo del Buen Jesús ${ }^{60}$. En el extremo del transepto sur de la catedral hay un sepulcro procedente de la capilla de la Comunión (Figura 5) que parece corresponder a este pariente de don Lope al figurar en uno de sus tres escudos las armas de los Mendoza. Este monumento funerario mantiene la tradicional fórmula del yacente, que en este caso representa a un eclesiástico con capa pluvial, mitra, y libro cerrado sobre el pecho ${ }^{61}$.

\footnotetext{
${ }^{59}$ A.H.D.S. Serie Catedral. Capilla de D. Lope 1527-1868, leg. 9, Autos obrados..., s. f.

${ }^{60}$ LÓPEZ FERREIRO (Historia..., vol. VII, 1904, 116), ya había apuntado acertadamente que en la capilla estaban, entre otros, los sepulcros del cardenal Martín López y de Pedro Siso, un regidor compostelano del que hablaremos a continuación; pero se equivocó López Ferreiro al situar el enterramiento del cardenal Martín López en el lienzo de la pared contigua al palacio arzobispal, ya que, como se especifica en la visita de 1767 , su tumba estaba situada en el muro este de la capilla: «junto a dicho colacteral del dulze nombre de Jesus se alla un nicho con el retrato de Martin Lopez cardenal de esta santa Yglesia y al lado del ebanjelio del altar maior otro con un rotulo que dize Pedro Siso rexidor y otro que dijeron dichos capellanes ser del conde de Mazeda porque cobraban de renta doze ferrados de zenteno») (A.H.D.S. Serie Catedral. Capilla de D. Lope 1527-1868, leg. 9, Autos obrados..., s. f.). Como constataremos al analizar el testamento de Pedro Siso, el altar del Buen Jesús estaba en el lado de la Epístola, y justo enfrente, en el lienzo oeste de la capilla, se disponían los monumentos funerarios de Pedro Siso y el conde de Maceda. Al respecto, véase infra n. 62, y el plano de fray Plácido Caamiña (Figuras 7 y 8).

${ }^{61}$ LÓPEZ FERREIRO (Historia..., vol. VII, 1904, 143); y CAAMAÑO MARTÍNEZ («EI arzobispo...», 39). Según este último autor, la organización de este sepulcro es idéntica al mausoleo de Garcí Ruiz de la Mota, el tesorero de la catedral de Burgos enterrado en la capilla de la Visitación de esa basílica castellana.
} 
Sobre el mausoleo de Pedro Siso tenemos, afortunadamente, una serie de noticias que nos permiten conocer su estructura general, a pesar de no conservarse ningún resto. Sabemos que este regidor compostelano establece en su testamento que se tenía que «fazer un arco en la dicha capilla del arzobispo Don Lopo en el lienzo de la parede questa frontero del altar del Buen Jesus, e de dicha sepultura, e en el dicho arco, se me haga mi bulto, como a los dichos mis complidores pareciere $\rangle^{62}$. La tumba de Siso, embutida en el lienzo oeste del recinto ${ }^{63}$, fue construida en 1535 por los canteros Alonso de Gontín y Rodrigo Díaz. Según las estipulaciones del contrato, los maestros «han de abrir en el lyenço de la parede de la capilla del arçobispo don Lopo frontero del altar del nonbre de Jesus vn arco e fazer el dicho arco de ocho pies e medio fasta nueve en largo e en ancho dos pies e medio fasta tres metydo en el gordor de la parede el qual dicho arco e pie derecho ha de caver debaxo del entablamento de la ventana e ha de ser fecho vna buelta byen graciosa e los pies derechos labrados de Romano la buelta por la parte de fuera de chorobines e de lo de dentro e de fuera llano e en encima del arco dos escudos de armas que para ello le diere debuxado con sus festones e en el antepecho otro escudo de las armas... con sus festones e acompañamiento e con vn letrero

${ }^{62}$ PÉREZ COSTANTI ( «La capilla de don Lope...», op. cit., $\mathrm{n}^{\circ}$ 1, 30 de marzo de 1891), afirmaba que había leído el testamento original de este regidor en un protocolo del año 1531 del escribano Macías Vázquez, dando además una breve noticia de su contenido. A pesar de revisar la documentación de ese año, no pude localizar el testamento, pero, sin embargo, hallé una copia notarial de la mencionada escritura fechada en 1740. En extracto, dice así: «Ytem mando que quando Dios fuese seruido de me lleuar desta presente vida mi cuerpo seya sepultado por manera de sepultura, o deposito, fasta en tanto que se faga mi sepultura de que auajo se hara mencion en la capilla del arzobispo Don Lopo, en la sepultura donde iacen sepultados mi padre e madre, e doña Maria Vermudez de Castro mi muger, e Ygnes Yañez Siso mi hermana. Ytem mando que mis complidores fagan fazer un arco en la dicha capilla del arzobispo Don Lopo en el lienzo de la parede questa frontero del altar del Buen Jesus, e de dicha sepultura, e en el dicho arco, se me haga mi bulto, como a los dichos mis complidores pareciere, e si por caso antes de mi falescimiento yo feziere fazer el dicho arcobulto e sepultura, mando que en ella me sepulten, e si por caso mis testamentarios lo fezieren despues de mi falescimiento mando que mis huesos seian trasladados y puestos alli. Ytem mando a los capellanes de la dicha capilla el mi lugar de Casal... en que el presente mora que fue de mi señora madre, con todo lo a ello anejo e perteneciente, con condicion que tenga por bien e consientan que se haga la dicha sepultura en el dicho lienzo de la dicha pared, y mas que seian obligados perpetuamente a dezir en cada un año dos misas cantadas...» (A.H.D.S. Serie Catedral. Capilla de D. Lope 15271868 , leg. 9 , s. f.).

${ }^{63}$ Estaba situado en el lado del Evangelio de la capilla, en el lienzo oeste según el plano de fray Plácido Caamiña (Figura 8). Al respecto, véase supra n. 60. Gracias a estos datos se puede intentar reconstruir la situación de los cuatro retablos de la capilla que, a mi entender, sería la siguiente: en el lienzo norte del recinto estaría colocado el altar mayor, en el este el altar del Buen Jesús, y en el muro oeste los otros dos retablos colaterales dedicados a santo Tomé y a santa Ana. 


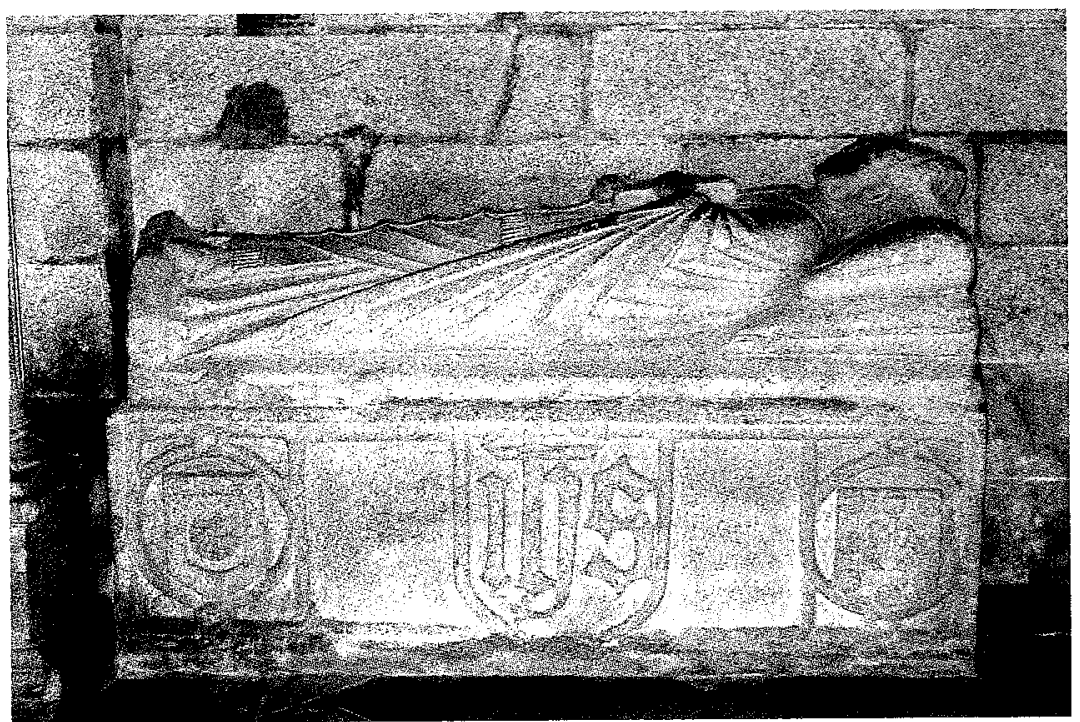

Figura 5.- Sepulcro del cardenal Martín López.

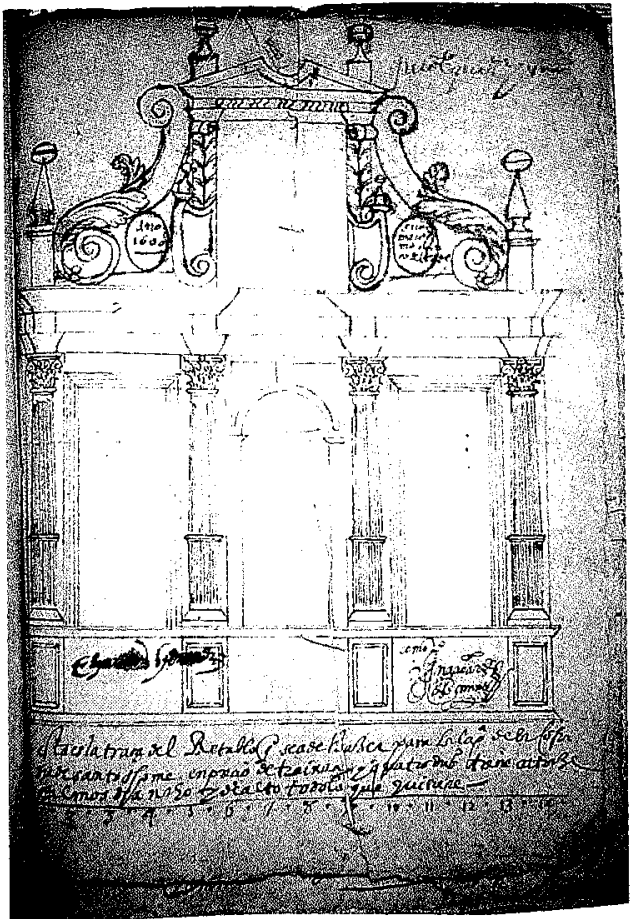

Figura 6.- Trazas del retablo de santo Tomé. 1600. Carlos de Meri (A.H.U.S.). 
de letras que para ello le diere; e debaxo del antepecho ha de aver vn entablamento que salga medio pie debaxo otro entablamento. E debaxo de la cama ha de yr el letrero e encima vn bulto de vn hombre armado recostado en dos almoadas sobre la mano derecha con su espada e puñal e vn leon a los pies» ${ }^{64}$. En el arcosolio de Pedro Siso se mantenían las viejas fórmulas medievales de los retratos funerarios de la nobleza gallega, todavía presentes en el siglo XVI. El difunto se representa recostado, fiel al estereotipo del durmiente, vuelto probablemente hacia el espectador y con la mano en la mejilla, manifestando claramente su condición social a través de las armas y la armadura, que exaltan su rango de caballero. Por lo que se puede deducir de la descripción del monumento, este lecho funerario no incorpora ningún avance tipológico que evidencie la aplicación de los nuevos principios renacentistas presentes desde los años veinte del siglo en el mausoleo más clásico de la catedral compostelana, el monumento funerario del maestrescuela don Diego de Castilla, instalado en la capilla de san Bartolomé ${ }^{6}$.

\section{ALGUNAS CONSIDERACIONES SOBRE LA ARQUITECTURA DE LA CAPILLA DE DON LOPE DE MENDOZA: SU CORO ALTO Y LA SACRISTÍA}

El plano de fray Plácido Caamiña (Figuras 7 y 8) es la fuente gráfica más importante que tenemos para conocer la estructura de la antigua capilla de don Lope de Mendoza. En él se manifiestan sus dimensiones arquitectónicas y su disposición, adosada a la catedral y ocupando la parte oriental del antiguo patio del palacio arzobispal. A este fundamental testimonio de 1768 tenemos que añadirle ahora otro plano trazado en el año 1739 por Simón Rodríguez que reproduce la cabecera de la catedral compostelana y toda la extensión de su crucero, un diseño que tuve la fortuna de reencontrar en los ricos fondos del archivo catedralicio, y del que anticipo un detalle correspondiente a la capilla gótica que estamos estu-

${ }^{64}$ LÓPEZ FERREIRO (Historia..., vol. VIII, apéndice XXI); y PÉREZ COSTANTI (Diccionario..., 242-243).

${ }^{65}$ Sobre este monumento funerario de don Diego de Castilla, que sirve como contrapunto estilístico del sepulcro de Pedro Siso, véase A. ROSENDE VALDÉS («El siglo XVI: Gótico y Renacimiento en la catedral compostelana», en Santiago, la catedral y la memoria del arte, Compostela, 2000, 168-170). Para profundizar en las características de los sepulcros gallegos del quinientos, véase M. CHAMOSO LAMAS («La escultura funeraria en Compostela desde 1500», Cuadernos de Estudios Gallegos, vol. XIX, 1964, 65-102; y A. ROSENDE VALDÉS («Un marco para a morte: o sepulcro galego no século XVI», en Galicia no Tempo. 1991, Santiago, 1991, 221-243).

Cuadernos de Estudios Gallegos, Tomo LII, Fascículo 118, Santiago 2005. (Págs. 347 - 385) 


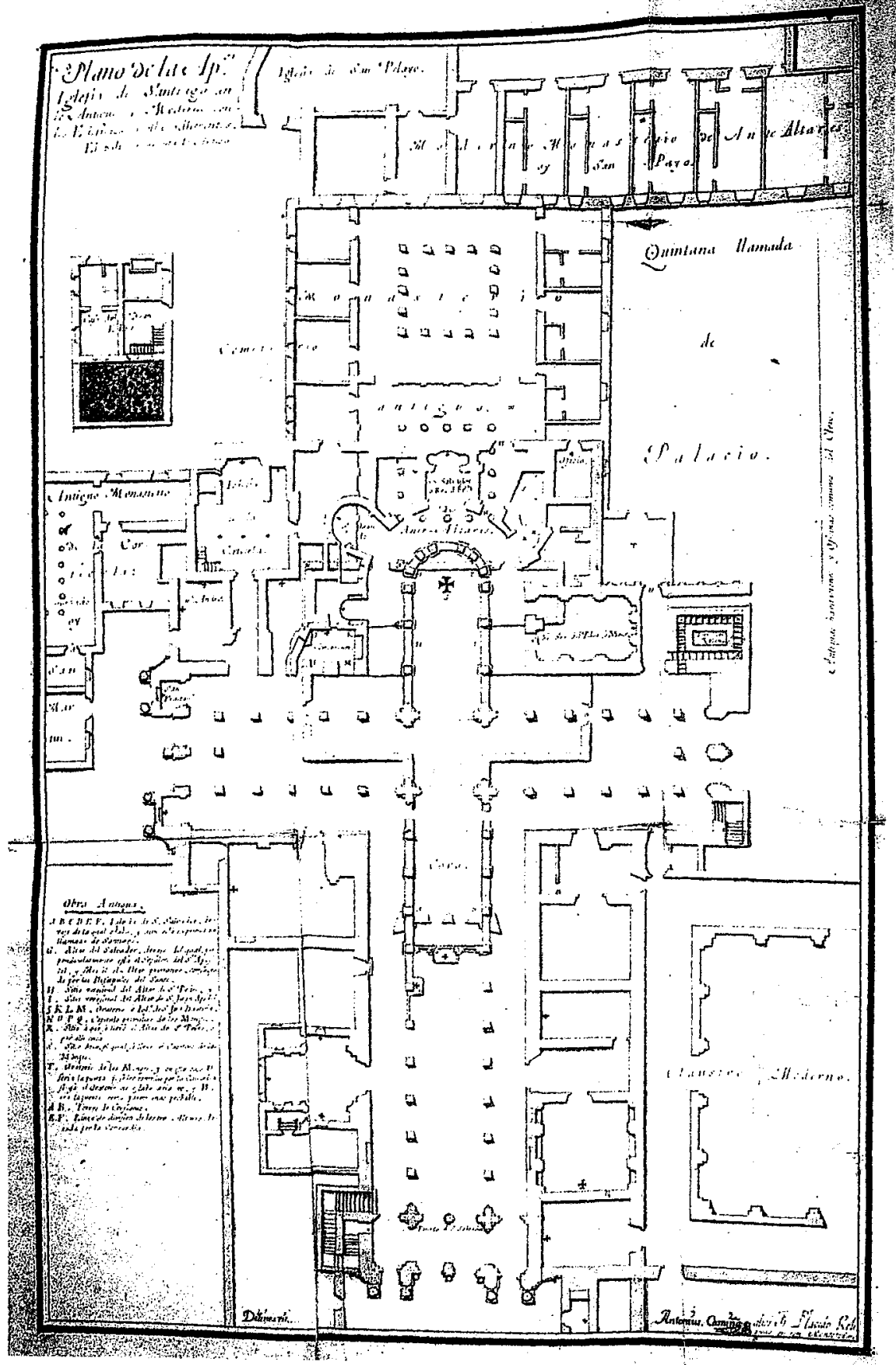

Figura 7.- Planta de la catedral de Santiago. 1768. Fray Plácido Caamiña (B.X.U.S.).

Cuadernos de Estudios Gallegos, Tomo LII, Fascículo 118, Santiago 2005. (Págs. 347 - 385) 


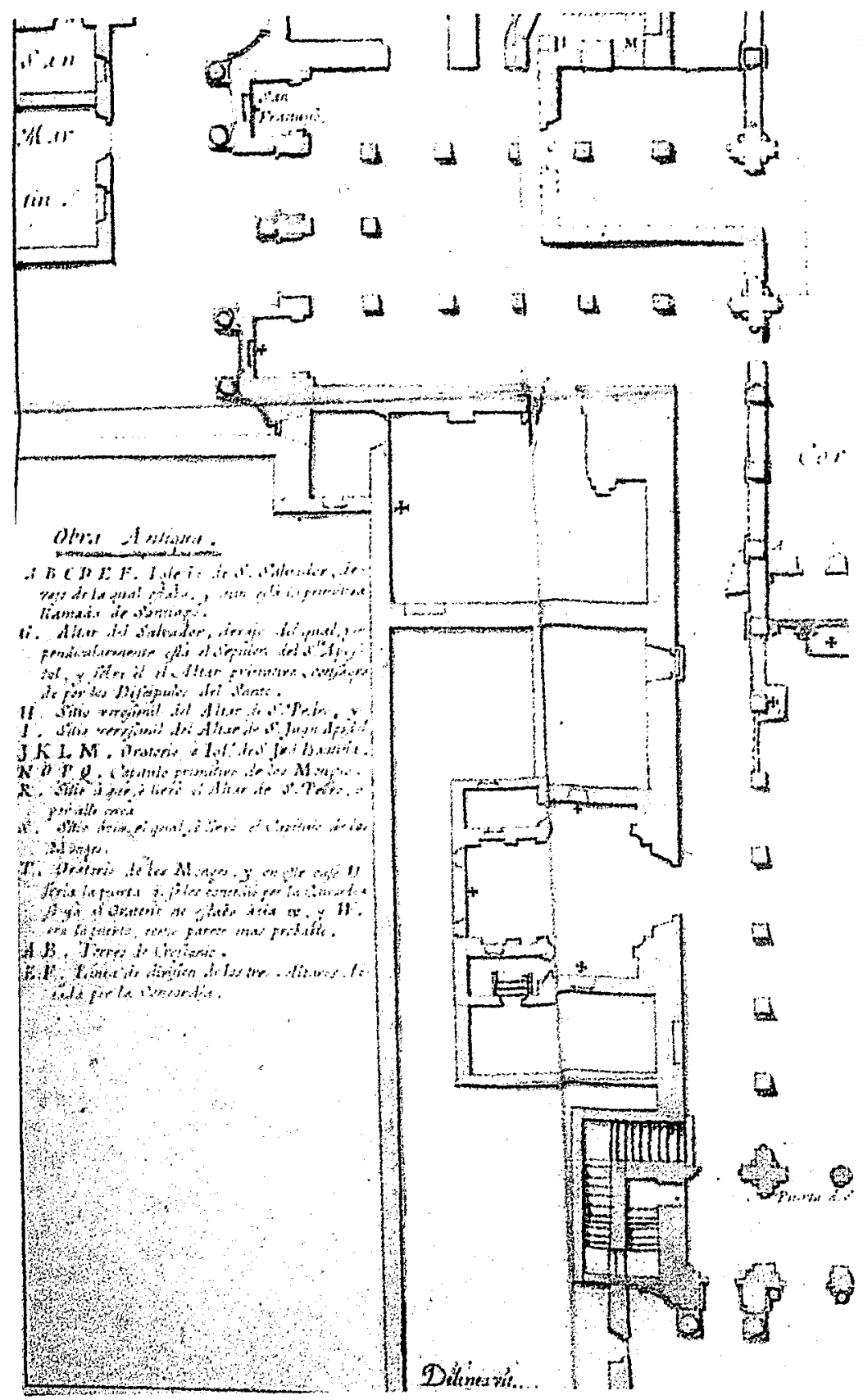

Figura 8.- Planta de la capilla de don Lope. 1768. Fray Plácido Caamiña (B.X.U.S.). 
diando $^{66}$ (Figura 9). Este croquis de Simón Rodríguez muestra dos entradas a la capilla de don Lope: una abierta en el segundo tramo del transepto norte, lo que vuelve a confirmar que el acceso a la estancia bajomedieval se efectuaba por una antigua puerta situada en la actual capilla dedicada a Santiago Matamoros ${ }^{67}$; y una segunda entrada ubicada en el primer tramo de ese mismo brazo norte. De este último acceso no teníamos ningún testimonio gráfico hasta la fecha, a pesar de que todavía quedan vestigios arquitectónicos de la puerta (Figura 10).

Esta nueva referencia, a pesar de las apariencias, no contradice, a mi juicio, el plano de Caamiña, sino que, por el contrario, lo complementa ${ }^{68}$. Simón Rodríguez se limitó a reproducir la planimetría del testero y crucero de la catedral, pues actuaba como perito en un conflicto jurisdiccional en el que la corporación catedralicia pretendía demostrar la inclusión de la parroquia de santa María de la Corticela dentro del ámbito de la basílica; por ese motivo, el arquitecto no tiene ningún interés en delinear el espacio interno de la capilla de don Lope, ajena totalmente a las estipulaciones del pleito. Pero quiero destacar que a pesar de no reproducir la catedral en su totalidad, la planta de Rodríguez, por su propia condición de documento oficial, es más precisa que la de fray Plácido Caamiña (Figura 7), un maestro que traza correctamente las escaleras de la torre del Reloj, las que suben al tesoro y el acceso a los cuerpos altos de la torre de la Carraca, pero se olvida de reproducir las escaleras que bajan a la cripta situada bajo el Pórtico de la Gloria y las de la torre de las Campanas, llegando incluso a suprimir de su diseño la estructura de esta torre sur del Obradoiro. Lo que demuestra el croquis de Rodríguez es que en el año 1739 todavía se utilizaba el primitivo acceso de la torre románica

\footnotetext{
${ }^{66}$ Como algunas partes de la planta están deterioradas, y en la actualidad se está restaurando, no puedo reproducirlo en su totalidad. Por los inefables caprichos del azar, este plano es totalmente inédito y hasta la fecha no ha sido catalogado ni reproducido; pero debo señalar que $\mathrm{M}^{\mathrm{a}} \mathrm{C}$. FOLGAR DE LA CALLE (Arquitectura gallega del siglo XVIII. Los Sarela, Santiago, 1985, 30), ya había mencionado su existencia, señalando además con absoluta precisión el legajo en el que se podía encontrar: A.C.S. Jurisdicción del Cabildo. Pleito con el cura de la Corticela, leg. 285. Quiero agradecer a todo el personal del archivo catedralicio: Arturo Iglesias, Francisco Sandoval, Luis Gómez y María Seijas, y especialmente a don José María Díaz Fernández, canónigo archiverobibliotecario de la catedral, todas las facilidades y atenciones que me dispensaron para poder estudiar y fotografiar este documento gráfico.

${ }^{67}$ Como había establecido VIGO TRASANCOS (La catedral..., 38).

${ }^{68} \mathrm{~A}$ pesar de que puede parecer que este nuevo plano (Figura 9) constata un doble acceso a la capilla de don Lope, esta posibilidad es remota, pues sería completamente contradictorio tanto con el propio diseño de Caamiña, que en líneas generales debe ser aceptado como un testimonio fidedigno de las dimensiones y disposición de la capilla gótica, como con la propia documentación conservada, que confirma la existencia de una entrada única.
} 


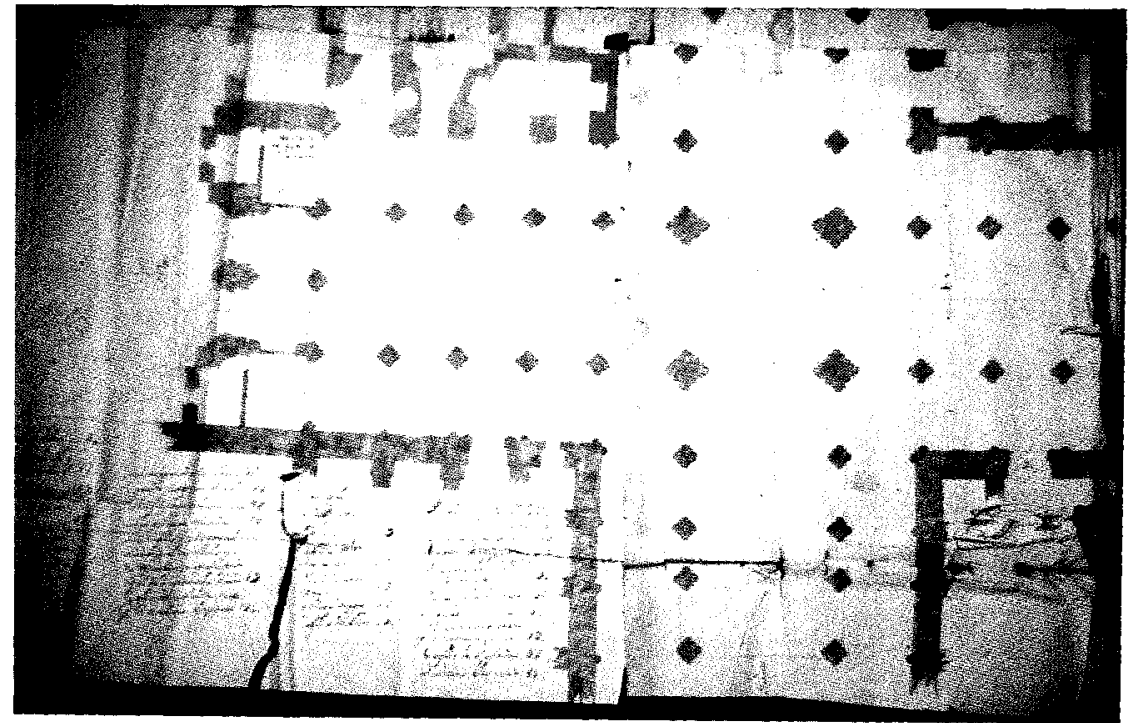

Figura 9.- Detalle del transepto norte de la catedral de Santiago y del cierre oriental de la capilla de don Lope. 1739. Simón Rodríguez (A.C.S.).

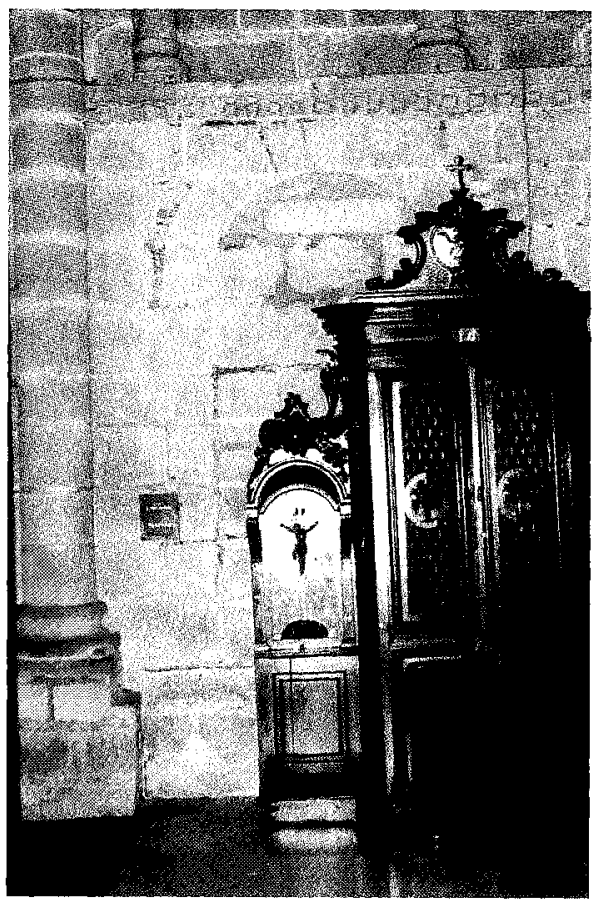

Figura 10.- Vestigios arquitectónicos del antiguo acceso de la torre románica del transepto norte de la catedral. 


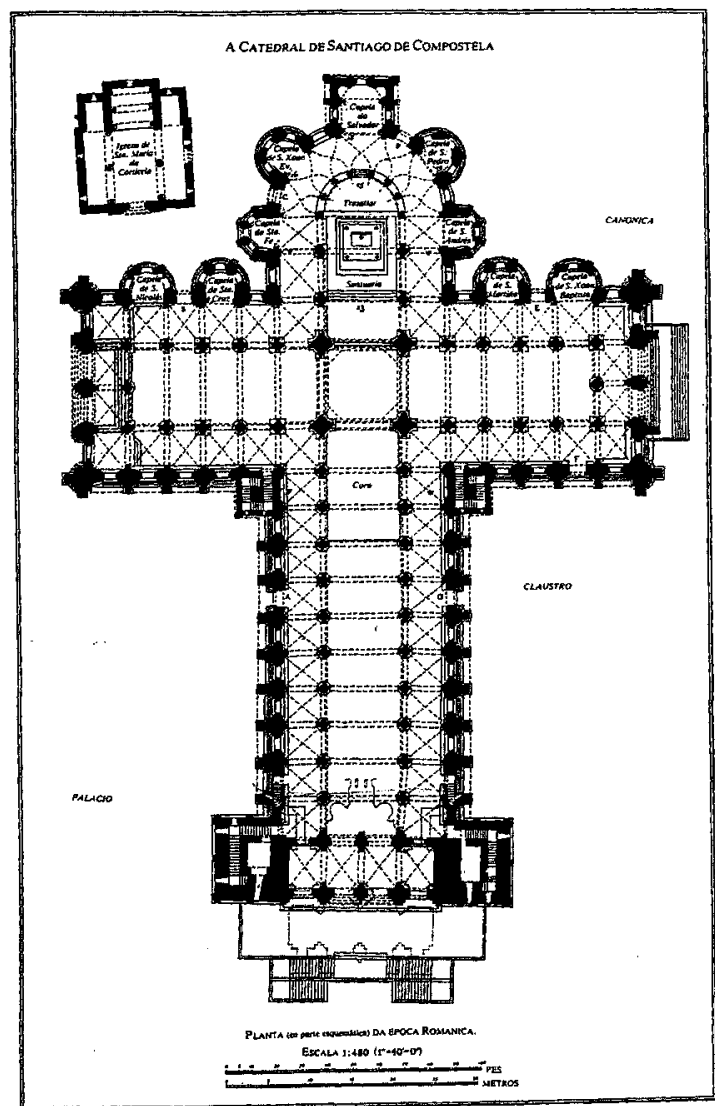

Figura 11.- Planta románica de la catedral de Santiago (K.J. Conant).

que, como recoge el Códice Calixtino, estaba situado en el transepto norte de la basílica $^{69}$, y que tal como se puede apreciar en la reconstrucción de la catedral románica de K.J. Conant (Figura 11), se levantaba justo en ese ángulo de la iglesia, ocupando un tramo de la catedral románica por cada uno de sus lados; las mismas dimensiones, en definitiva, que se manifiestan en la masa cúbica que reproduce Caamiña en su plano y que, como acertadamente se ha apuntado, rompía la regularidad cuadrangular de la capilla de don Lope ${ }^{70}$.

${ }^{69}$ CONANT, K.J., Arquitectura románica da catedral de Santiago de Compostela, Santiago, 1983 [ $1^{\text {a }}$ ed., en inglés en 1926], 195.

${ }^{70}$ VIGO TRASANCOS, A., La catedral..., 38.

Cuadernos de Estudios Gallegos, Tomo LII, Fascículo 118, Santiago 2005. (Págs. 347 - 385) 
Dejemos por un momento estos testimonios gráficos y pasemos, antes de pergeñar una posible explicación del cometido de esta puerta, a dar cuenta de las nuevas noticias que logré reunir sobre el coro de la capilla, una información complementaria que, en mi opinión, nos ayudará a interpretar correctamente los planos de los dos arquitectos barrocos. En el cabildo celebrado en la sacristía de la capilla el 10 abril 1747 se acuerda reparar la «tribuna»" ${ }^{71}$, es decir, el coro alto del recinto gótico ${ }^{72}$. Las obras se emprenden en algún momento indeterminado de ese año, ya que en los libros de fábrica de 1748 se da puntual cuenta del «coste de la composicion del choro» ${ }^{73}$. En los trabajos de renovación se llevaron a cabo una serie de reparaciones puntuales por parte de un cantero, que durante 8

${ }^{71}$ «Asimismo se le dio facultad a dicho D. Juan Baptista Rodríguez [era el capellán mayordomo], para que disponga se componga la tribuna de esta motiuada capilla segun y de la manera que antes de aora verbalmente se le hauia encargado por los señores capellanes al señor D. Antonio Losada tambien capellan quien por sus ocupaciones no pudo ponerlo en ejecucion, y que para los gastos que se causasen en esta composicion de las mas halajas que ay en dicha capilla y la necesiten» (A.H.D.S. Serie Catedral. Autos capitulares 1740-1828, leg. 14, fol. 24).

${ }^{72}$ Quiero aclarar que en numerosos documentos este espacio elevado es denominado por los capellanes «tribuna», pero siempre es utilizada esta expresión como sinónimo de «coro alto». Este uso indiscriminado y el enorme vacío documental provocó algunas ambigüedades que pretendo evitar. Por lo tanto, el recinto que voy a estudiar en este apartado no se corresponde estrictamente con lo que se entiende por «la tribuna de la capilla de don Lope», es decir, una estancia privada, de carácter señorial, desde la que el fundador podía asistir a los oficios religiosos sin ser visto. Es posible que la referencia a una «ventana sobre el altar mayor, desde donde podían asistir al culto los arzobispos y sus familiares» ( $c f r$. supra n. 12), se refiera a la tribuna en vez de hacer referencia, como se creía, a una «vidriera sobre el altar mayor», y, por lo tanto, el prelado habilitase un pequeño palco en el muro norte de la capilla, anexo a su palacio y con comunicación directa con él. En relación al término «tribuna» como sinónimo de «coro alto» quiero citar simplemente como testimonio un pasaje muy significativo de un protocolo notarial ya conocido por PÉREZ COSTANTI ( «La capilla de don Lope...», op. cit., $\mathrm{n}^{\circ} 3,30 \mathrm{de}$ abril de 1891), que curiosamente no fue recogido por este autor en la transcripción del documento a la que dedica su artículo, pero, en cambio, figura en el escrito original, un poder que otorgaron los capellanes de don Lope a varios procuradores para promover el pleito contra la catedral, litigio que se inició por los graves perjuicios que les ocasionaba la nueva capilla de la Comunión. En el fragmento aludido, los capellanes exigen al cabildo que «se formalizase la tribuna o coro para en el celebrar los capellanes las visperas, oras canonicas y oficios deuidos que tienen obligazion y acostumbrauan hacerlo» (A.H.U.S. Notario R. Paz de Ponte y Andrade. Prot. $n^{\circ} 7.260$ (1784), fol. 16 v.). Como podemos comprobar, la «tribuna o coro» se refiere al ámbito destinado al rezo y al canto de la comunidad eclesiástica, y nada tiene que ver con un espacio señorial privado.

${ }^{73}$ Todas las referencias documentales sobre el antiguo coro de la capilla de don Lope de Mendoza se encuentran en el único libro de fábrica que se conserva. cfr. A.H.D.S. Serie Catedral. Capilla de D. Lope. Cuentas de fábrica $1744-1824$, leg. 15 , fols. 10v.-11v. 
días se dedicó a reforzar su estructura ${ }^{74}$, asegurando también el macizo de la escalera pétrea que subía al coro $^{75}$ y que tenía además una puerta con su correspondiente cerradura ${ }^{76}$. Pero, según lo referido en la contabilidad de la capilla, el grueso de las obras correspondió a un carpintero y un peón ${ }^{77}$, que además de confeccionar dos bancos, renuevan el coro, lo que parece indicar que esta parte alta de la capilla era de madera ${ }^{78}$.

Una última noticia sobre este recinto elevado de la antigua capilla de don Lope es que tenía, por lo menos, una ventana o una vidriera con doble cristalera ${ }^{79}$.

Otro dato que resulta muy significativo es que en la mencionada visita de agosto de 1767 no se hace referencia al coro, lo que puede indicar que su acceso no se

\footnotetext{
${ }^{74}$ «Ytem de ocho dias que ocupo el cantero en dicha obra, y cada uno a tres reales y medio son 28 reales vellon». También hay una referencia a «dos canzorros de canteria que se ingirieron en la zepa para la maior seguridad de dicho coro 23 reales y medio vellon incluso su carreto asta la puerta de la yglesia») (A.H.D.S., idem, idem).

${ }^{75} \mathrm{La}$ escalera del coro alto se menciona, como se explicó anteriormente, en la concordia del 28 de mayo de 1685 entre los capellanes y la cofradía de san José, según la cual se le permite poner «en dicha capilla deuajo de la escalera por donde se sube al coro della» el arca de la cera (A.H.U.S. Notario Juan Martínez de Cea. Prot. $\mathrm{n}^{\circ} 1411$ (1685), fols. 38-39). De lo referido en las cuentas de fábrica se puede deducir que la escalera era de piedra: se mencionan «picos y siceles para arar los pasos de la escalera y abrir los encages de los canzorros», también se transportaron «ocho carros de pizarra para el mazizo de la escalera... dos piedras, y un taco de canteria para la escalera... Ytem de dos carros de varro» (A.H.D.S. Serie Catedral. Capilla de D. Lope. Cuentas de fábrica 1744-1824, leg. 15 , fols. $10 \mathrm{v} .-11 \mathrm{v}$.).

${ }^{76}$ Hay una partida de 10 reales por «una zerradura nueua para la puerta del coro» (A.H.D.S., idem, idem).

${ }_{77} \ll 22$ dias que ocupo el carpintero al mismo precio [que el cantero] son 77 reales vellon. Ytem a un peon que ocupo 15 dias a real y medio son 22 reales y medio»(A.H.D.S., ídem, idem).

${ }^{78}$ Por desgracia, no se pueden establecer con total seguridad las características del coro, pero los datos parecen indicar que era de madera. Hay un apunte de « 26 tablas que se gastaron en dicha composicion y la del altar de Santa Ana»; y si bien es cierto que al carpintero también se le paga por «la echura de dos bancos del choro 16 reales», la madera para este trabajo se compra aparte: «ytem de quatro tablas de obra para los dos bancos del coro quince reales vellon. ytem de quatro pontones para los mismos bancos cinco reales». Por lo tanto, como es fundamentalmente la madera el material empleado para «componer el coro", parece razonable pensar que era de madera -no olvidemos que la cantería se usa sólo en la escalera y en las cepas de refuerzo del coro-. También se hace referencia a «un baron de hierro que sostenia el coro viejo», retirado una vez reforzada la cepa del coro con cantería, como ya se ha mencionado, y este soporte no parece muy apropiado para sostener un cuerpo pétreo. Por último, figura un gasto de « 49 reales por clavos para clavar los pontones contra las vigas del piso»; y además de mencionarse la compra de «una viga que se echo a dicho coro doze reales vellon», hay también un pago de trece reales y medio por «cinco pontones y una barandilla larga» (A.H.D.S., idem, idem).

${ }^{79}$ En las cuentas de la composición del coro figura una partida de «seis reales vellon al vidriero que compuso la del coro por dentro y fuera» (A.H.D.S., idem, idem).
} 
situaba en el interior de la capilla, pues de otra forma no se comprende bien su omisión en la relación notarial ${ }^{80}$.

La vieja construcción gótica fue demolida completamente y en su solar, como sabemos, se levantó la actual rotonda ilustrada con el doble objetivo de servir de panteón al arzobispo Rajoy y de ser utilizada como comulgatorio de la catedral, especialmente durante los años santos ${ }^{81}$. El proyecto de Domingo Lois Monteagudo, por diferentes motivos que van desde su propia condición de arquitecto académico formado en Roma hasta cuestiones de índole simbólica y geométrica, tuvo que adaptarse a las condiciones del espacio preexistente ${ }^{82}$, una solución que además solventaba las propias necesidades que imponía la funcionalidad de la nueva capilla ${ }^{83}$.

Es extraño que los capellanes de don Lope alegasen en el pleito con la catedral que «experimentan la novedad de que se le dio otra construccion minorando su ambito» ${ }^{84}$; es decir, sostenían que la nueva rotonda era más pequeña que el recinto medieval originario. Si cotejamos una planta trazada por Miguel Ferro Caaveiro en 1794 con el diseño de Caamiña (Figura 12 y 8) podemos comprobar que la capilla de la Comunión es algo más grande respecto a la anterior de don Lope, extendiéndose un tramo más hacia el oeste; sin embargo, su actual nártex de acceso, que coincide exactamente con el pequeño espacio anexo al macizo de la torre románica trazado por fray Plácido y ocupa en los croquis de los dos arquitectos dos tramos de la catedral románica, no forma parte de la capilla actual. De esta forma, la nueva construcción, a pesar de dilatarse hacia poniente, no incorpora el vestíbulo, al contrario de lo que ocurría en la obra gótica, y, por ello, no debe sorprendernos que los capellanes de don Lope se quejasen de la reducción del recinto ${ }^{85}$.

\footnotetext{
${ }^{80}$ Don Ramón Pillado, el visitador del arzobispo Rajoy, estaba acompañado por un notario que iba tomando nota del estado de la capilla y de todos sus elementos. Como no se menciona ningún acceso ni se hace referencia alguna al coro, parece razonable pensar que su entrada fuese externa e independiente del recinto principal.

${ }^{81}$ Para conocer su historía constructiva, véase A. VIGO TRASANCOS («Domingo Lois Monteagudo...», 450-466 y La catedral..., 95-111); y F. SINGUL LORENZO (La ciudad..., 198-207).

${ }^{82}$ J.M ${ }^{\star}$. CAAMAÑO MARTÍNEZ («El Gotico», en La Catedral de Santiago de Compostela, Barcelona 1977,257 ), había señalado la posibilidad de que mediante un sistema de trompas se pasase de la planta cuadrangular de la capilla de don Lope a un octógono, cubriéndose el recinto con una bóveda de crucería estrellada. El nuevo diseño de la capilla de la Comunión, según VIGO TRASANCOS («Lois Monteagudo...», 456), se adapta a la configuración primitiva ya que se basa en los principios geométricos de un círculo inscrito en un octógono a partir de una matriz cuadrada.

${ }^{83}$ VIGO TRASANCOS, A., La catedral..., 96-97.

${ }^{84}$ A.H.U.S. Notario R. Paz de Ponte y Andrade. Prot. $n^{\circ} 7.260$ (1784), fol. 16.

${ }^{85} \mathrm{La}$ forma rotonda de la nueva capilla, al no aprovechar los espacios angulares de la anterior estructura cuadrangular, crear un efecto óptico de reducción espacial a pesar de ampliar su superficie. 


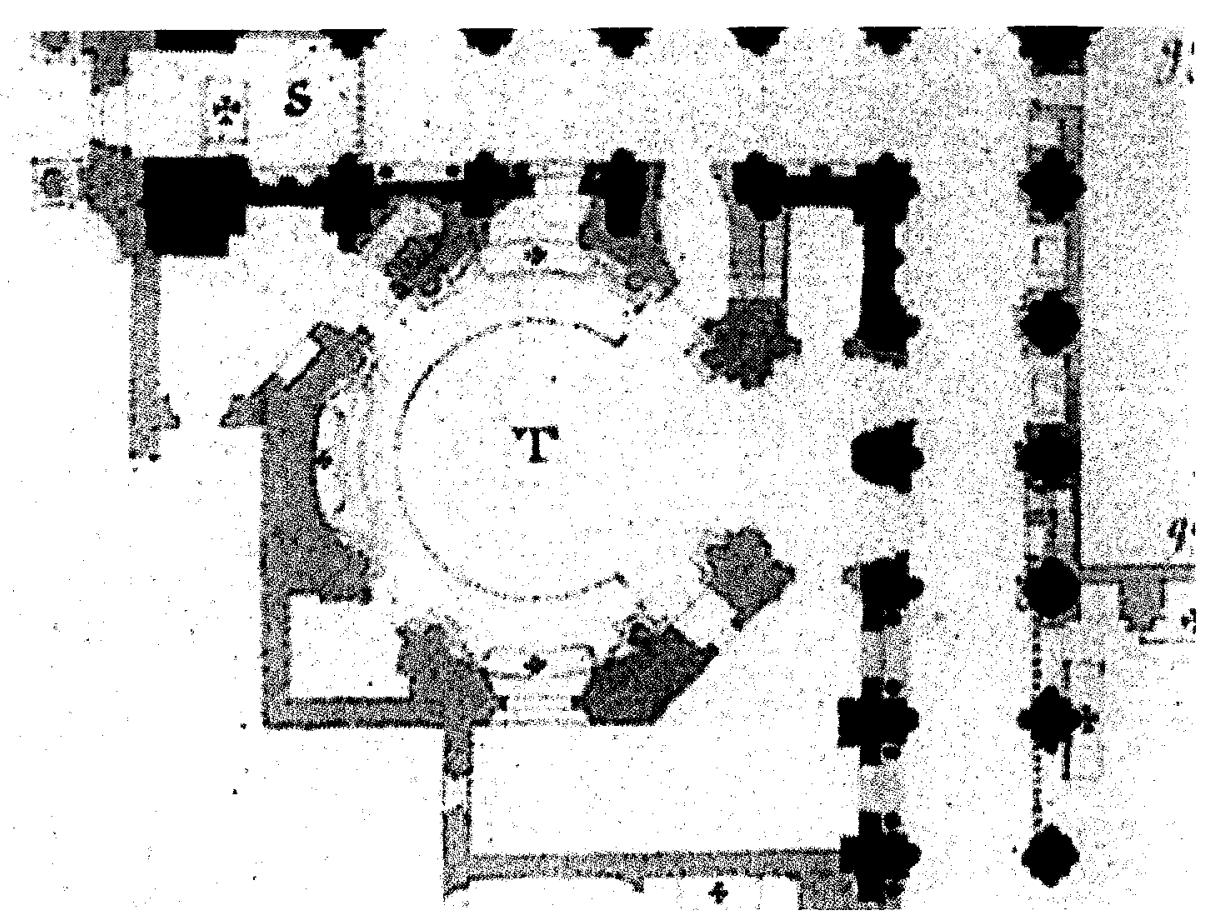

Figura 12.- Planta de la capilla de la Comunión. 1794. Miguel Ferro Caaveiro (A.C.S.).

El nártex es un espacio residual que se dispone fuera de la estructura centralizada de la nueva rotonda, pero también fue transformado por el proyecto de Lois Monteagudo, que decidió sustituir el viejo acceso del transepto norte por la doble entrada abierta a la nave del Evangelio de la catedral (Figura 13) con la intención de favorecer la axialidad de la rotonda y la circulación en el comulgatorio, manteniendo además la orientación establecida por la contigua capilla del Cristo de Burgos $^{86}$. Encima del vestíbulo hay una estancia en desuso (Figura 14), construida al tiempo que se levantaba la nueva capilla. A este espacio alto se accede por unas escaleras de caracol (Figura 18), después de atravesar un pequeño cuarto situado justo en el tramo donde se levantaba la antigua torre medieval del transepto nor$\mathrm{te}^{87}$, que a pesar de las transformaciones sufridas, todavía manifiesta en su muro este los restos de un primitivo arco románico (Figura 15).

\footnotetext{
${ }^{86}$ VIGO TRASANCOS, A., La catedral..., 97, 99.

${ }^{87}$ Ya se indicó anteriormente que esta torre tenía un antiguo acceso por el primer tramo del transepto norte de la catedral (Figuras 9, 10 y 11).
} 
Pues bien, en el ámbito residual situado sobre el actual acceso a la capilla de la Comunión (Figura 14) se disponía, en mi opinión, el antiguo coro de la capilla de don Lope ${ }^{88}$. Renovado completamente ${ }^{89}$, nada queda de su vieja estructura, salvo los datos documentales que, como sabemos, lo describen someramente.

El coro alto de la capilla tenía que estar situado a los pies del recinto gótico ya que, como se explicó a lo largo del trabajo, en los demás muros estaban colocados el altar mayor, los tres retablos colaterales y los diversos monumentos funerarios. Si prescindimos de la masa de la torre románica, la única ubicación posible que resta es el referido espacio secundario que figura en el plano de fray Plácido Caamiña, y sabemos por la documentación que el coro estaba elevado, por lo que se adapta perfectamente a la estructura del croquis de 1768. Tenía, aproximadamente, las mismas dimensiones que la estancia actual, como indican las coincidencias espaciales entre los dos planos referidos de Ferro y Caamiña (Figuras 12 y 8), a no ser que se aprovechase también la estructura superior de la torre, abarcando de esa forma toda la parte alta del lienzo meridional de la capilla. Su puerta de entrada sería probablemente el primitivo acceso de la torre románica, que estaba ubicado en el primer tramo del transepto norte, como testimonia el plano de Rodrígue $z^{90}$, y tal vez se conservaba todavía parte del primitivo cuadrante de la escalinata románica, pues, como se explicó, la escalera del coro era de piedra. Es posible también que en el pequeño hueco que se aprecia en la planta de Caamiña y que corresponde al flanco oeste de la torre románica colocase la cofradía de san José el mueble de la cera'.

\footnotetext{
${ }^{88}$ Con anterioridad, A. VIGO TRASANCOS (La catedral..., 38), al estudiar el plano de Caamiña que reproduce la capilla de don Lope, ya había sugerido la posibilidad de que en el recinto secundario anexo a la masa de la torre románica estuviese situada una tribuna alta. La nueva documentación hallada parece confirmar esta hipótesis.

${ }^{89}$ En la fotografía de este cuarto situado encima del nártex de la capilla de la Comunión (Figura 14), completamente reformado al levantarse la rotonda, y actualmente en desuso, se aprecia a la derecha de la imagen una gran arcada de comunicación con la capilla que no se utiliza. Al fondo se observa una ventana enrejada que da a una serie de almacenes de la catedral y desde la que se puede observar el patio y el palacio arzobispal. Los ventanales de la izquierda corresponden a los dos vanos que se abren hacia la nave del Evangelio de la catedral, situados encima de las dos portadas del nártex de la actual capilla (Figura 13), y es posible que a una de esas dos ventanas se refiera la cuenta del vidriero «que compuso la del coro por dentro y fuera» (A.H.D.S. Serie Catedral. Capilla de D. Lope. Cuentas de fábrica 1744-1824, leg. 15, fols. 10v.-11v.).

${ }^{90}$ Fray Plácido Caamiña no reproduce esta puerta en su diseño porque a este maestro le interesaba más esbozar los espacios de la basílica e ilustrar gráficamente el estudio altomedieval de fray Bernardo Foyo.

${ }^{91} \mathrm{Al}$ respecto, vease supra n. 47.
} 


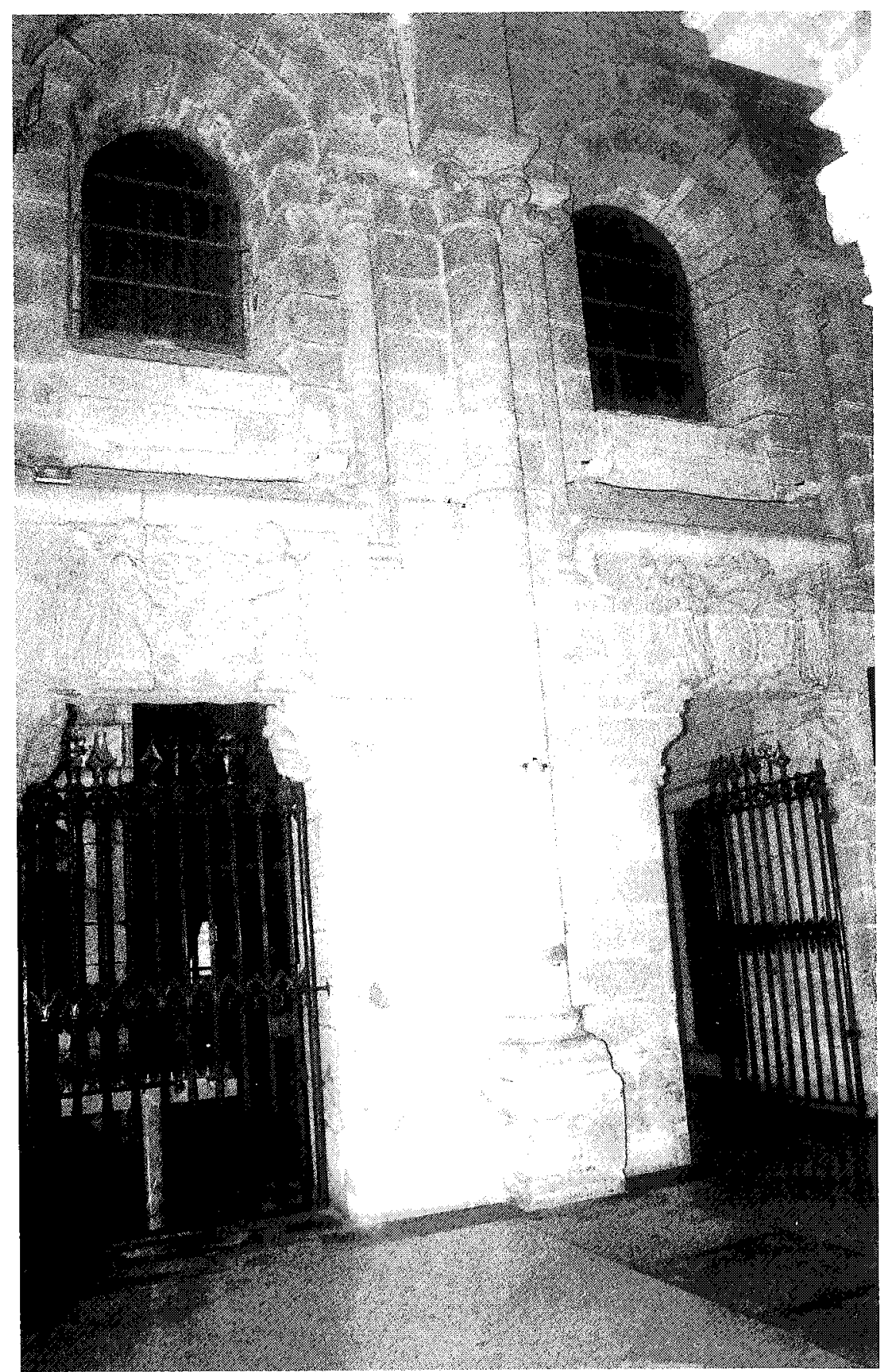

Figura 13.- Acceso actual al nártex de la capilla de la Comunión.

Cuadernos de Estudios Gallegos, Tomo LIl, Fascículo 118, Santiago 2005. (Págs. 347 - 385) 


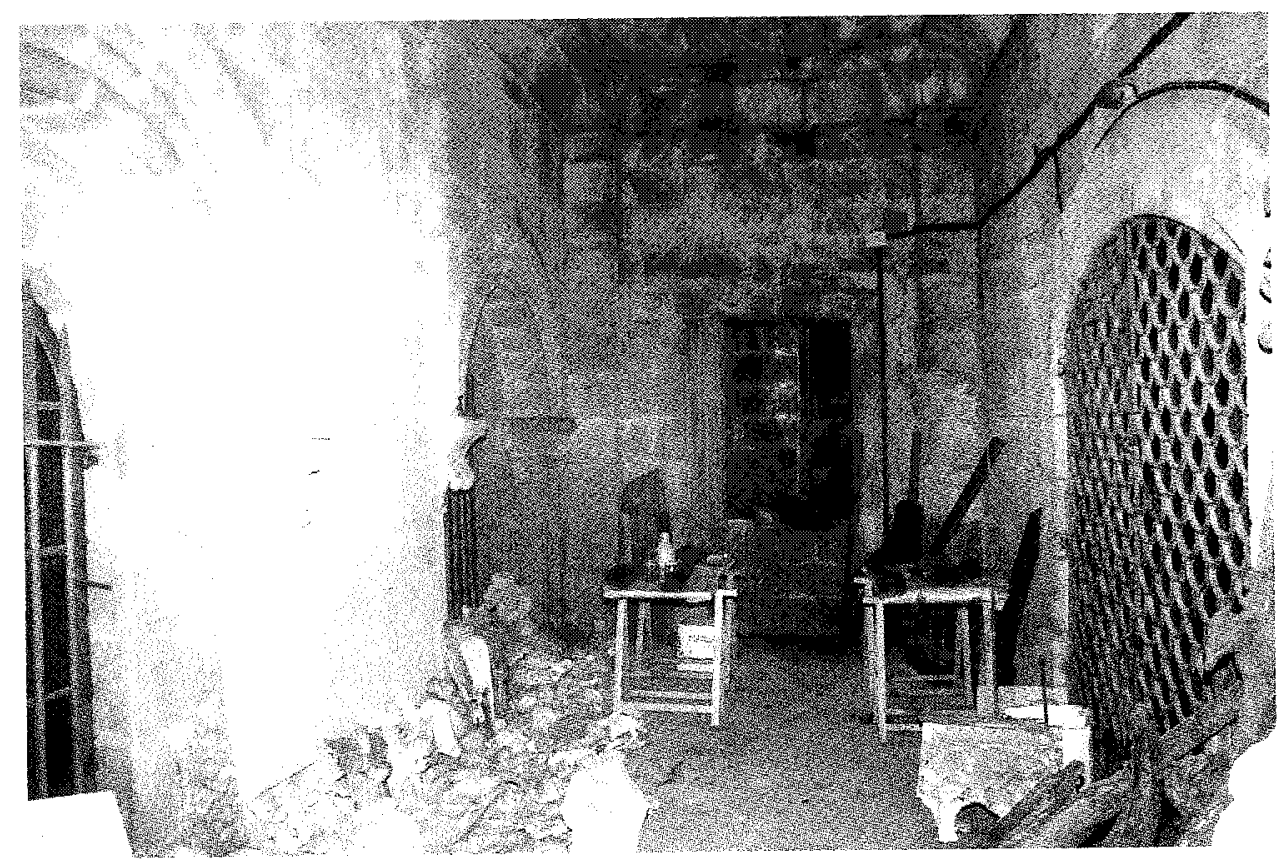

Figura 14.- Estancia situada encima del nártex de la capilla de la Comunión.

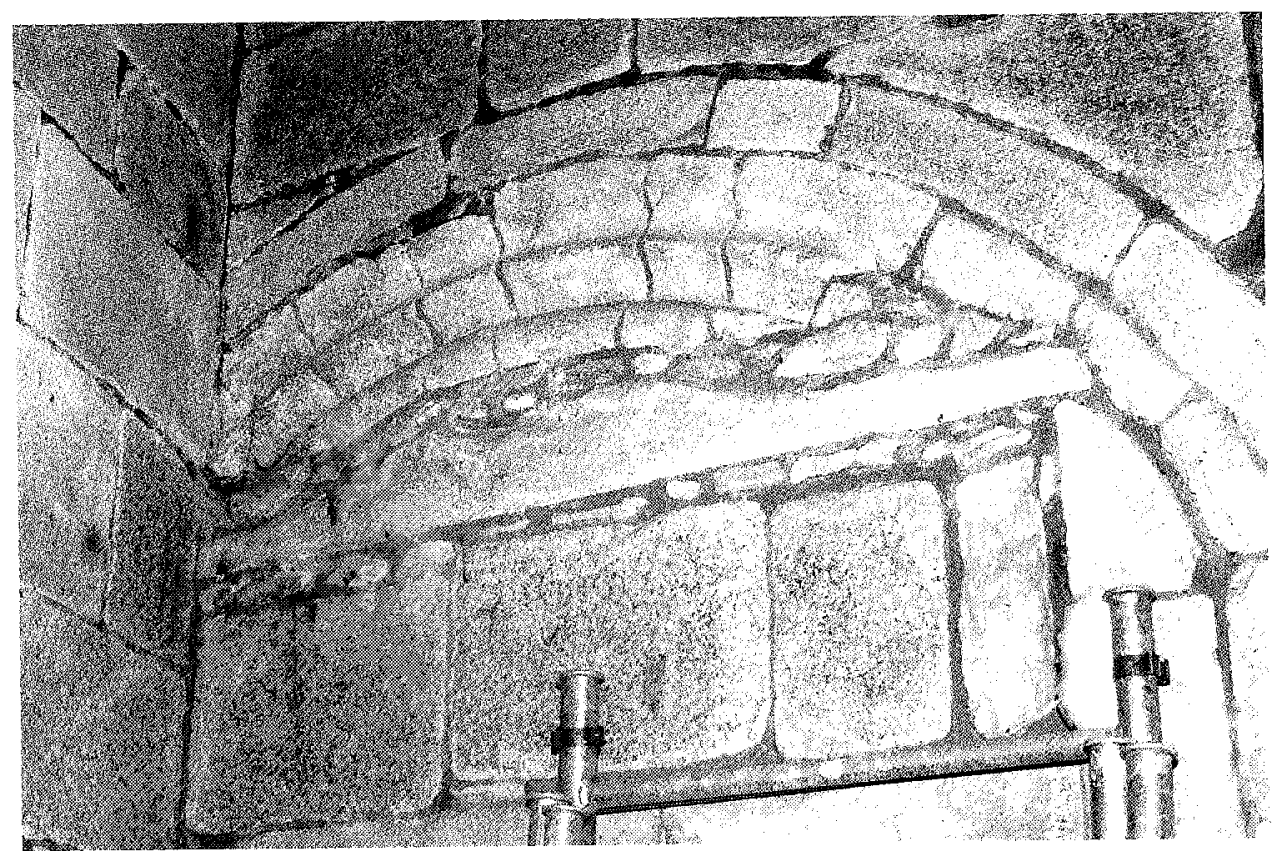

Figura 15.- Vestigios de un arco de la antigua torre románica del transepto norte de la catedral.

Cuadernos de Estudios Gallegos, Tomo LII, Fascículo 118, Santiago 2005. (Págs. 347 - 385) 


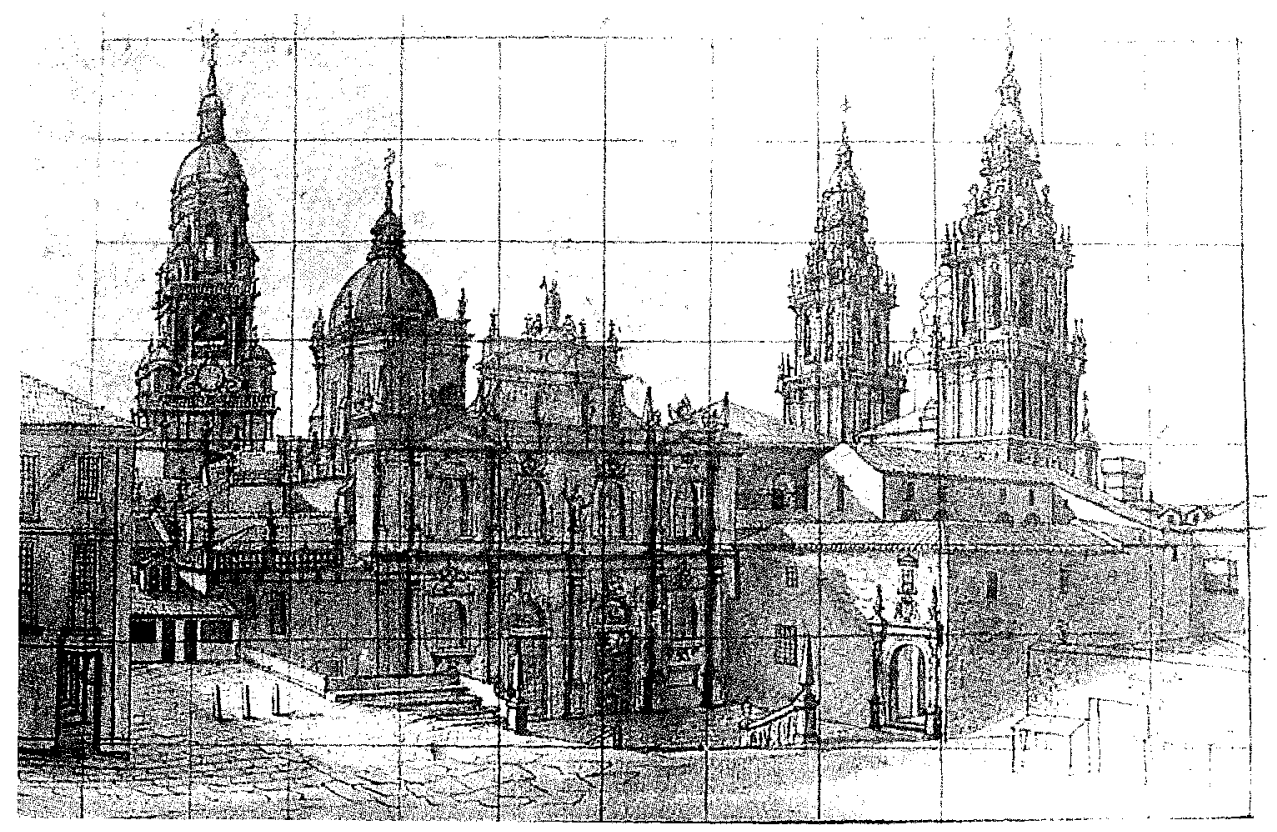

Figura 16.- Fachada de la Azabachería en 1838 (R. Gil Rey).

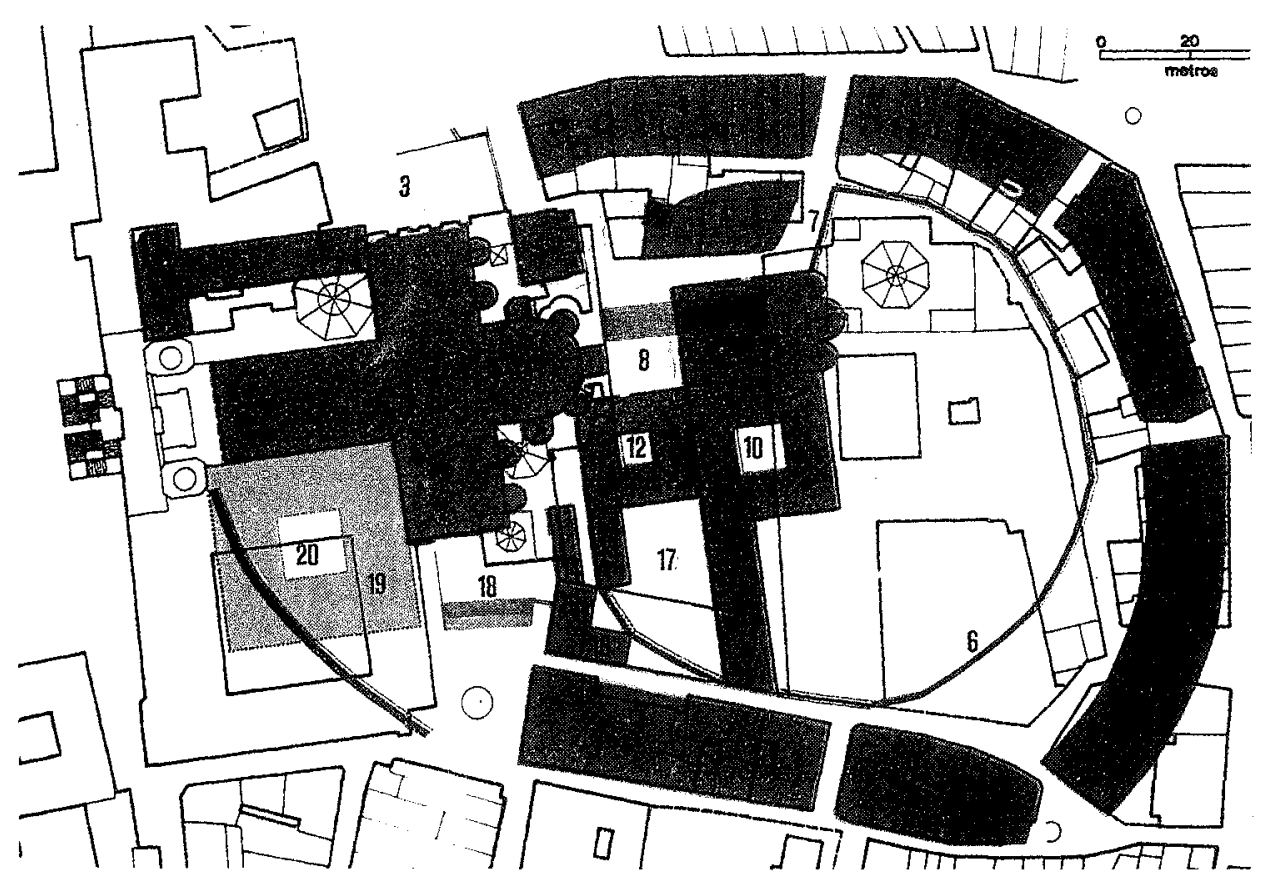

Figura 17.- La ciudad de Compostela hacia 1150 (F. López Alsina). 


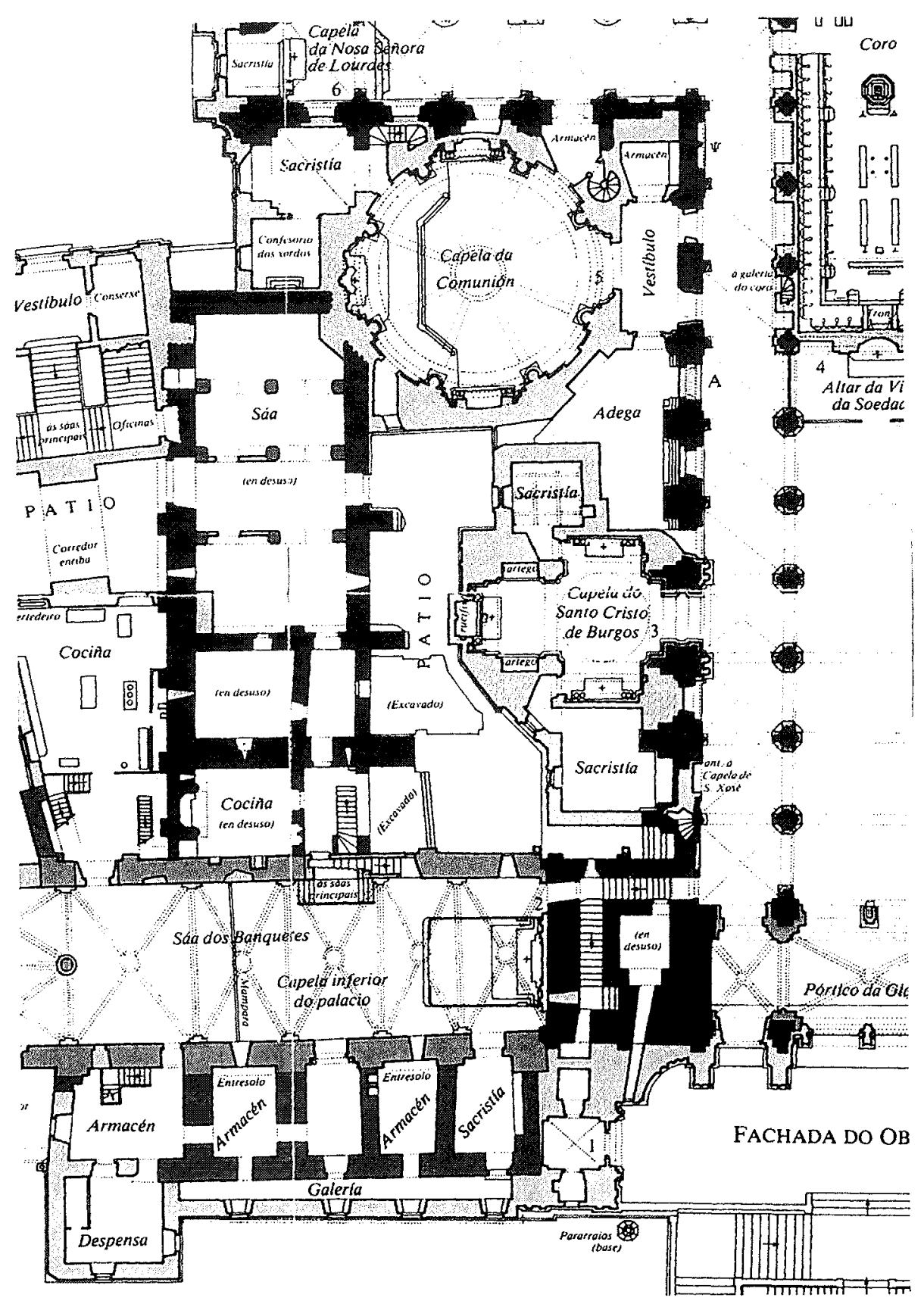

Figura 18.- Planta de la capilla de la Comunión y del palacio arzobispal (K.J. Conant). 


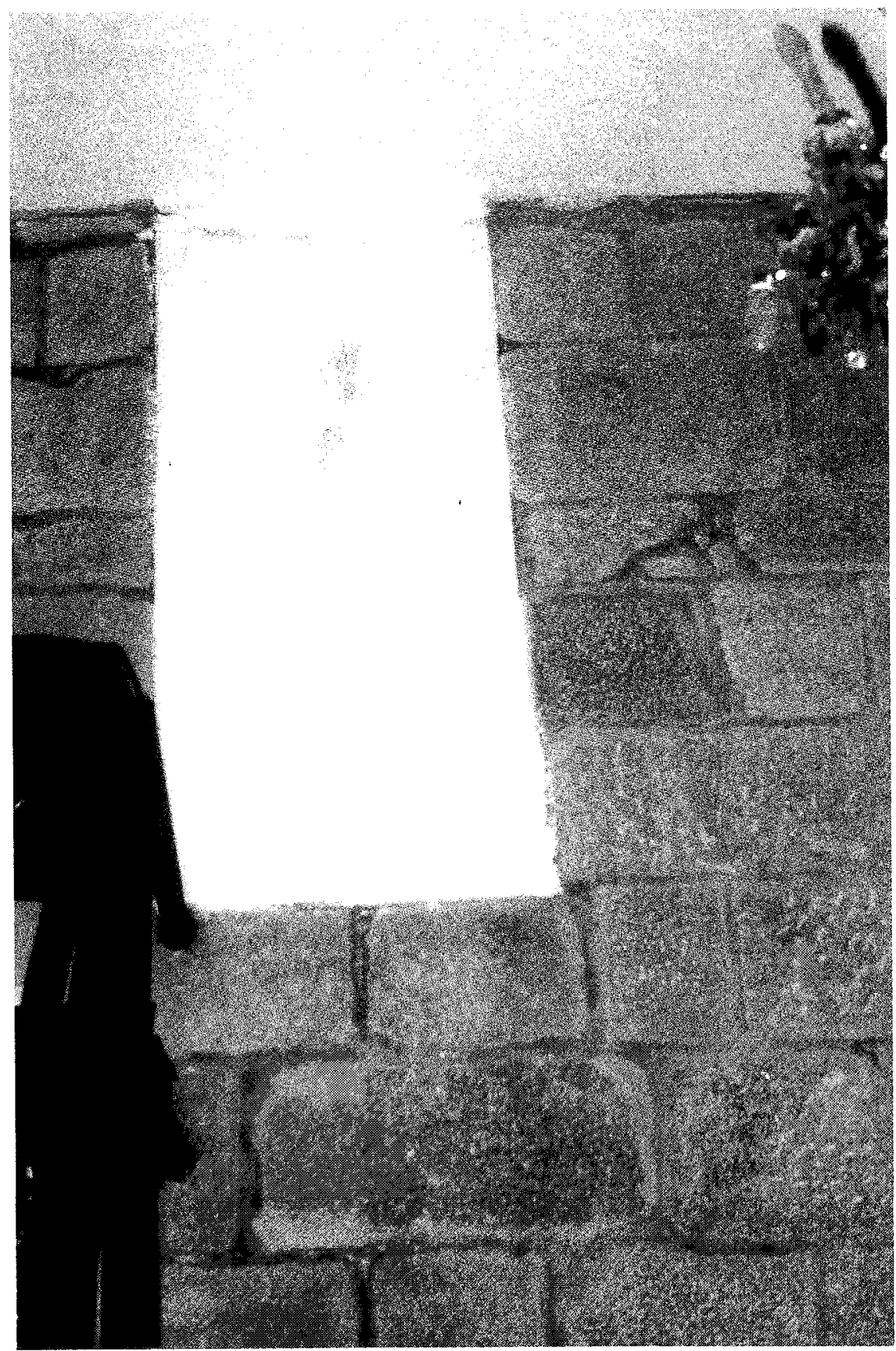

Figura 19.- Posibles vestigios del antiguo acceso que comunicaba el palacio arzobispal con la capilla de don Lope. 
El estudio de la sacristía de la capilla presenta todavía mayores problemas que el coro alto debido a las escasas informaciones que tenemos sobre este recinto. Lo que es inequívoco, al menos desde 1740, es que en este espacio se celebraban en numerosas ocasiones los cabildos de la capilla ${ }^{92}$. También se deduce de la visita de don Bernardo Pillado en agosto de 1767 que era una pieza contigua a la estancia principal, y en ese momento no se utilizaba; su elemento más destacado era «un cajon grande de madera de castaño biejo con algunas dibiciones $\rangle^{93}$. La condición de pieza separada a la que se pasa aludida en la documentación parece coincidir con el recinto adosado al ángulo nororiental del cierre norte de la capilla que figura en el plano de fray Plácido (Figura 8), un espacio unido al palacio arzobispal que ya había sido propuesto como una posible estancia destinada a sacristía ${ }^{94}$.

El diseño de Caamiña también deja constancia de la fachada de la Azabachería, prácticamente rematada por esos años, y del cierre del antiguo frontis oriental del palacio arzobispal, construido durante el episcopado de Alonso III de Fonseca, y que conocemos gracias al dibujo de 1838 de R. Gil Rey (Figura 16), realizado poco tiempo antes de ser destruido este viejo frente renacentista para dejar paso a la fachada actual. Como sabemos, el palacio de Gelmírez sufrió muchas transformaciones y añadidos a lo largo de los siglos, y es difícil precisar su configuración original (Figura 17). De todas formas, en época bajomedieval se llevaron a cabo una serie de restauraciones y añadidos hacia su flanco oriental, como la llamada sala gótica y las estancias situadas sobre ella. El arzobispo don Lope de Mendoza tuvo una intervención destacada en esta zona, conocida como el palacio de los Manrique, terminando las obras de la parte adyacente a la capilla de la Virgen del Perdón ${ }^{95}$, y por ello, quiero llamar la atención sobre una noticia que recoge J.M ${ }^{\text {a }}$ Zepedano y que quizá nos ayude a resolver el problema de la escalera de comuni-

${ }^{92}$ Como indican expresamente algunas actas capitulares conservadas del periodo 1740-1767. cfr: A.H.D.S. Serie Catedral. Autos capitulares 1740-1828, leg. 14.

${ }_{93}$ ky abiendo su merced pasado con asistencia de mi escribano y los cinco capellanes a la pieza que antes serbia de sacrestia de dicha capilla se allo un cajon grande de madera de castaño biejo con algunas dibiciones» (A.H.D.S. Serie Catedral. Capilla de D. Lope 1527-1868, leg. 9, Autos obrados..., s. f.).

${ }^{94}$ A. VIGO TRASANCOS (La catedral..., 40), ya había sugerido la posibilidad de que esta pequeña estancia posterior fuese la sacristía de la capilla de don Lope.

${ }^{95}$ Sobre las actuaciones en esta parte del palacio arzobispal $c f r$. A. LÓPEZ FERREIRO (Historia...,vol. VII, 1904, 111); R. YZQUIERDO PERRÍN («Santiago de Compostela, la ciudad construida. Arquitectura medieval», en Santiago de Compostela: ciudad y peregrino, Santiago, 2000, 259), y J.M. GARCÍA IGLESIAS (ed.), El palacio de Gelmirez, Santiago, 2001, 37-38. 
cación entre la capilla y el palacio ${ }^{96}$. Sobre esta cuestión, en un pasaje dedicado a la capilla de don Lope, afirma Zepedano: «Tiene buena sacristía, por la cual el fundador venía con frecuencia de palacio a hacer oración. Aquella entrada se ha tapiado después» ${ }^{97}$.

Debemos tener en cuenta que con la erección de la capilla de la Comunión se alteró la antigua sacristía medieval dando paso a una nueva dependencia renova$\mathrm{da}^{98}$, pero, si comparamos la planta de la sacristía delineada por el propio Miguel Ferro en 1794 con el diseño de Caamiña (Figuras 12 y 8), comprobamos que se aprecian diferencias en la configuración de las dos vicarías, pero no en su localización. Para mayor complicación e incertidumbre, el arzobispo don Miguel García Cuesta, hacia la mitad del siglo XIX, lleva a cabo importantes reformas en la zona este del palacio, lindante con la capilla, edificando además, como ya se mencionó, una nueva fachada retranqueada con respecto a su línea primitiva, lo que, a su vez, obligó a cerrar el flanco visible de la catedral por ese lado.

En la actualidad, según constata el conocido plano de K.J. Conant (Figura 18), se dispone contigua a la sacristía una estancia denominada Confesionario de Sordos. Pues bien, en el muro occidental de esta pieza, limítrofe con el palacio arzobispal, todavía se aprecia un posible vestigio del antiguo acceso que mencionaba Zepedano (Figura 19). Esta pared estaba encalada, y al picarla para dejar la piedra a la vista apareció un hueco relleno de cascotes, que más tarde se revocó, como se aprecia en la fotografía, para evitar irregularidades en el aparejo del muro ${ }^{99}$.

\footnotetext{
${ }^{96} \mathrm{La}$ existencia de una escalera que comunicaba palacio y capilla fue dada a conocer por LÓPEZ FERREIRO (Historia..., vol. VII, 1904, 116); y CAAMAÑO MARTÍNEZ («El arzobispo...», 35).

${ }^{97}$ ZEPEDANO Y CARNERO, J.M ${ }^{\mathrm{a}}$, op. cit., 166.

${ }^{98} \mathrm{Al}$ respecto, véase A. VIGO TRASANCOS, La catedral..., 96-97, y apéndice XXXVIII.

${ }^{99}$ Agradezco a don Armando Raposo, encargado de obras de la catedral, estas informaciones. También quiero dejar constancia de mi reconocimiento a don Alejandro Barral, canónigo director del Museo, por haberme facilitado el acceso a numerosas dependencias de la catedral.
} 